\title{
Technical Non-Invasive Study of an 18th Century Novo-Hispanic Panel Painting
}

\author{
Miguel Pérez ${ }^{1,2}$, Nathael Cano ${ }^{1,3}$, ${ }^{\text {, José Luis Ruvalcaba-Sil }}{ }^{1}$, Alejandro Mitrani ${ }^{1}$ and Oscar G. de Lucio ${ }^{1, *(\mathbb{C})}$ \\ 1 Laboratorio Nacional de Ciencias para la Investigación y la Conservación del Patrimonio Cultural, \\ Instituto de Física, Universidad Nacional Autónoma de México, Apartado Postal 20-364, \\ Ciudad de México 01000, Mexico; miguel.pf@ciencias.unam.mx (M.P.); nathcano@comunidad.unam.mx (N.C.); \\ sil@fisica.unam.mx (J.L.R.-S.); mitrani@fisica.unam.mx (A.M.) \\ 2 Posgrado en Ciencia e Ingeniería de Materiales, Universidad Nacional Autónoma de México, \\ Ciudad de México 04510, Mexico \\ 3 Posgrado en Historia del Arte, Universidad Nacional Autónoma de México, \\ Ciudad de México 04510, Mexico \\ * Correspondence: olucio@ciencias.unam.mx
}

\section{check for} updates

Citation: Pérez, M.; Cano, N.; Ruvalcaba-Sil, J.L.; Mitrani, A.; de Lucio, O.G. Technical

Non-Invasive Study of an 18 th Century Novo-Hispanic Panel Painting. Heritage 2021, 4, 3676-3696. https://doi.org/10.3390/ heritage 4040202

Academic Editors: Daniel

Vazquez-Molini and Antonio Alvarez Fernandez-Balbuena

Received: 31 August 2021 Accepted: 13 October 2021 Published: 19 October 2021

Publisher's Note: MDPI stays neutral with regard to jurisdictional claims in published maps and institutional affiliations.

Copyright: (c) 2021 by the authors. Licensee MDPI, Basel, Switzerland. This article is an open access article distributed under the terms and conditions of the Creative Commons Attribution (CC BY) license (https:// creativecommons.org/licenses/by/ $4.0 /)$.

\begin{abstract}
Purísima Concepción, a large-format and unusual panel painting attributed to the 18th century, based on style and the common aspect of the visual tradition of the Virgin Mary found in the Viceroyalty of New Spain, is sheltered at the Museo Ex-convento San Agustin Acolman-INAH, México, an institution opened in late 1920, and one of the oldest museums in México. In this work, we present the material characterization of the surface layer of the painting by means of a non-invasive methodology, resulting from the combination of imaging and spectroscopic techniques. Analysis of hyperspectral images employing methods such as spectral angle mapper and principal component analysis allowed us to describe spatial distribution of the pigments and manufacturing methods, while XRF and FORS allowed us to record the complex and diverse color palette employed to achieve effects such as brightness, hue, saturation, and even the covering power of this painting.
\end{abstract}

Keywords: hyperspectral imaging; 18th century painting; FORS; XRF

\section{Introduction}

The study of painting in México is an important challenge due to the number of preserved artworks over a long period (16th-21st centuries) of time, with different pictorial traditions. In this research area, each technical study provides a piece of the puzzle, and contributes to the understanding of the heritage legacy developed through generations.

Purísima Concepción is an artifact of time and technique, and an artistic document in which different plastic and formal solutions can be studied. Its research strategy, defined by the study of its technology, materiality, and state of conservation through imaging and spectroscopic techniques, can complement the understanding of its temporality and material meaning of its production related to the 16th, 17th, and 18th centuries. By using imaging techniques, underlayer versions representing the Virgin Mary were recently discovered, as shown in [1], and the study of those layers will help understand the changes and formulations of its meaning. Meanwhile, the upper layer composition of Virgin Mary coronated by the angels, related to the 18th century, and the relevance of the Museo Exconvento San Agustin Acolman-INAH are discussed in this paper, and should provide a starting point for further and deeper studies of the currently hidden layers. The painting technique from the 18th century Novo-Hispanic period is scarcely studied, and it is unknown if there was a continuity of materials, anonymous painters, and geography. This research also seeks to provide an insight on such subjects.

The study of cultural heritage requires the use of non-invasive techniques and a multidisciplinary approach, in order to generate significant knowledge while preserving 
the studied objects. It has been necessary to develop methodologies where complementary techniques provide pieces of information that, when assembled, deliver the whole picture on the material properties and historical importance of an object. It is in this fashion that XRF spectroscopy data provides unequivocally elemental information in order to discriminate the material composition of a pigment, and FORS information provides a chemical signature of pigments and binders. Both are known to be powerful techniques, but are limited to analyze a single point, and usually require complex interpretations if a detailed description of the manufacture of an object is required. In contrast, some imaging techniques, such as digital radiography, ultraviolet photography, and even visible photography, can provide global information on a given object, and usually enhance details on the production of the studied object.

Hyperspectral imaging (HIS) combines properties of both spectroscopic and imaging techniques. Therefore, it is not limited to a local analysis (as with spectroscopic techniques), but instead, it can deliver a global description of the studied object. The generated images contain physical or chemical information, describing the distribution maps of certain materials. Therefore, results are not limited to a mere material study, but they can also provide-through an adequate analysis and interpretation-insights on the manufacturing process of the object, information regarding later interventions or modifications, and even its preservation state. HSI analysis has recently proven to be useful for heritage sciences [2-6]. In fact, it has become a well appreciated analysis technique due to its intrinsic characteristics: it is a non-invasive and portable technique which provides results over large areas in a relatively short time.

As recent examples of the use of HSI in heritage science studies, we have: the work by Pérez et al. [7], where different manufacturing stages were identified in the painting The Pentecost by Baltasar de Echave Orio (1558-1619); the work by Padoan et al. [8], in which HSI was used to monitor preservation and aging conditions of historical documents; the study by Sun et al. [9], where different degrees of flaking deterioration were evaluated in mural paintings at the Mogao Grottoes by using NIR-his; and the work of Hou et al. [10], where a combination of HSI information and multivariable analysis algorithms were employed to create a virtual restoration of ancient Chinese Qing dynasty paintings.

\subsection{Description of the Painting}

The Purísima Concepción painting (see Figure 1) depicts Mary, expectant, her delicate face and smooth skin are accompanied by wide and flowing hair, a pair of ruby earrings set in fine gold hang from her ears, and a pearl necklace hangs from her neck. The Virgin looks towards the devotee, and the hands are fixed in a prayerful position. These, in turn, frame the golden christogram on her womb, announcing her future motherhood. His elongated figure, covered with fine cloth, stands on cherubs and the inverted waning moon. (Genesis 3, 15 and Lk 1,28). Behind her, the reddish mid-afternoon sun peeks out, and at the top, her head is accompanied by a stellarium, two angels hold the great imperial crown, composed of the golden circlet of jewels, the crimson reddish lining and three arches. The Holy Spirit witnesses the event, and the blazing sunlight opens the clouds of heaven. In the lower plane, a horizon of warm waters, represented by blue hues and white lights, ends in a continental terrain. On this island firm, the palm, the cypress, and a palm tree appear stoically, accompanied by a lily with a recent shoot and a rose bush with soft and rounded brushstrokes. On the periphery, a simulated frame, with a golden appearance, presents pebbles, shells, and black tendrils made with the point of a round brush.

The visual tradition of this painting had been associated with the characteristics of the art of New Spain which shows variants of the iconography of Tota Pulchra, which arrived in America in 16th century, and had continuity almost up to the 18th century [1]. The support of this image is a rectangular panel measuring $258 \mathrm{~cm} \times 165 \mathrm{~cm}$, and is made up of five live-joint planks and three crossbars measuring $11 \mathrm{~cm} \times 165 \mathrm{~cm}$ wide each. Tangentially cut and brown in color, the plank and crossbar wood are distinguished by a large presence of knots and a rough surface finish due to the roughing of the material with a possible 
hatchet. The reinforcement between crossbars and planks also coincides with the insertion of forging nails through the front and an iron ring located in the upper center of the panel, possibly to hold it to the wall.

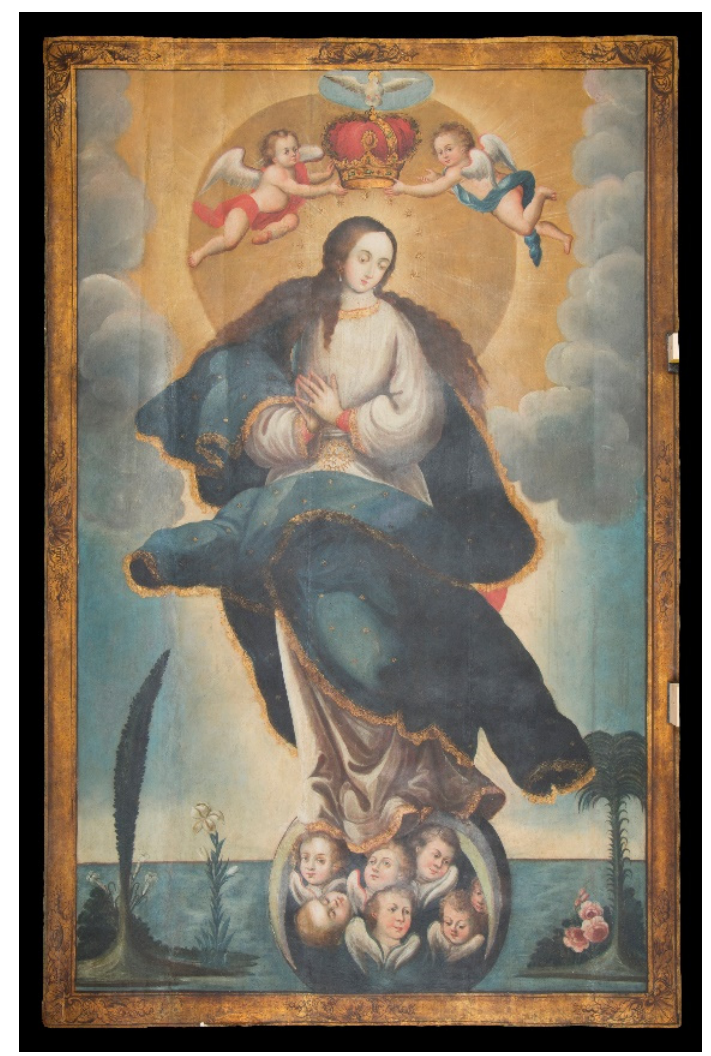

Figure 1. Visible image of Purísima Concepción. Museo Exconvento de Acolman-INAH, México.

Specially in Spain between the 15th and 17th centuries, the size, format and quality of the wood used to support paintings were directly based on an economy controlled by the regulations stipulated in ordinances. The diptych or triptych panels, with dimensions of up to $300 \mathrm{~cm}$ high by $250 \mathrm{~cm}$ wide, gave rise to altarpieces that, in some cases, reached great monumentality $[11,12]$. Due to the magnitude of these altarpieces, their execution depended on the collaboration of several artists. The use of wood as a support for paintings lasted during the three centuries of the viceroyalty of New Spain with basically the same construction technology, but during the eighteenth century, its use declined when compared to canvas [13].

\subsection{Analytical Techniques}

\subsubsection{Visible (VIS) and Ultraviolet (UV) Imaging}

The use of VIS and UV fluorescence as complementary imaging techniques provide information regarding the manufacturing process of the artwork. The painting was examined using a lamp UVP mod. B-100AP in long wave $(365 \mathrm{~nm})$, and was recorded with a DSLR Nikon D7100, lens NIKKOR 24-120.

\subsubsection{Hyperspectral Imaging (HSI)}

Hyperspectral images were generated using a Surface Optics 710VP camera, based on a dispersive system and a silicon sensor, providing a $4.5 \mathrm{~nm}$ spectral resolution in the $375 \mathrm{~nm}$ to $1047 \mathrm{~nm}$ range. Image dimensions are $696 \times 520$ pixels. Two $3200 \mathrm{~K}$ halogen lamps illuminate the object, and its intensity is determined right in front of the artwork using a solar power meter H110 series from Anaheim Scientific. Verification of the wavelength calibration is achieved by using yellow, blue, red, and green reflectance standards 
CSS-04-020 AS-01178-060. Deconvolution of the light source and detector contributions were calculated with Spectral Radiance Analysis Toolkit v3.5 using a Spectralon certified reflectance standard (model SRT-99-050 AA-00821-000) with a $5 \mathrm{~cm} \times 5 \mathrm{~cm}$ reflective area. Classification, image analysis, and generation of hypercubes was performed with Harris Geospatial Solutions ENVI 5.5 software. HSI analysis methods used in this work allowed us to generate different images: pseudo color IR; spectral angle mapper (SAM); UV fluorescence; PCA-RGB composite image; and single PC images, which are described in detail in the work of Perez et al. [7], and references therein. Such images permit a detailed description of the techniques involved in the manufacture of the Purísima Concepción.

In brief, the classification workflow was: (i) images were background-subtracted and normalized to rule out contributions from light source and detector efficiency; (ii) endmembers were determined using the pixel purity index (PPI) criteria, and resulting pixels were processed following the process described in the work of Veganzones et al. [14] and Kale et al. [15]; (iii) endmembers were mapped by using the ENVI-SAM algorithm, thus resulting in an artificially colored image, where each color corresponds with a material with a characteristic spectrum; (iv) optimization of angle thresholds was achieved by using the ENVI rule classifier tool to determine the correct threshold angle for each class, and the results were tuned by examination of the corresponding angle distribution histograms, as in the work of Foglini et al. [16].

Principal component analysis (PCA) was performed to provide a direct classification of regions with spectral information variations, which could not be easily distinguishable in each of the single-band images. Resulting images provide a reduced set, in which material, spectral, or even manufacturing features are condensed. Most of the data variance is included in the first PC, thus we propose that an RGB-PCA image conformed with the first three PCs will significantly enhance such features. Mathematically, each PC is determined by a linear combination of the wavelengths, thus providing insights on chemical or physical properties linked with the associated spectra. We have shown in a previous work [7] that it is possible to go even further by considering a multidisciplinary approach for PCA image interpretation, allowing the description of manufacturing details on the studied object.

\subsubsection{Fiber Optic Reflectance Spectroscopy (FORS)}

FORS spectral information was generated and recorded by a FieldSpect-4 ASD system, with spectra in the visible, near infrared (NIR), and short-wave infrared (SWIR) wavelengths. Spectral resolution is $3 \mathrm{~nm}$ for the visible and NIR regions $(300-1000 \mathrm{~nm})$, and $10 \mathrm{~nm}$ for the remaining region of the spectra $(1000-2500 \mathrm{~nm})$. The analysis area is about $1 \mathrm{~cm}^{2}$, and requires the probe to be in contact with the studied object. The system employs a D65 illuminant, and spectra acquisition time was set at $0.2 \mathrm{~s}$. The system is routinely calibrated by an ASD Inc. certified reflectance standard (AS-02035-000CSTM-SRM-990-362).

\subsubsection{X-ray Fluorescence Spectroscopy (XRF)}

A home built portable X-ray system (SANDRA) was used for recording the elemental composition of the studied object, this system and its applications are described in detail elsewhere [17]. In brief, the system employed a Mo X-ray source collimated to a $1 \mathrm{~mm}$ area, and an Amptek SDD detector with detection angle fixed at $45^{\circ}$. Calibration of the system is achieved by using a NIST multicomponent glass standard reference material (SRM 1412). Irradiation parameters were $45 \mathrm{kV}, 0.200 \mathrm{~mA}$ with a recording time of 90 seconds, and no filters were used during the spectra acquisition. Spectra analysis and deconvolution was performed by means of ESRF-BLISS PyMca software.

Due to the existence of an underlying painting, interpretation of XRF data could be complex, since the range of photons in matter allow them to penetrate hundreds of micrometers, encompassing not only the surface, but most of the layers of the painting. However, the physics ruling the interactions between X-rays and solids, such as the attenuation of photons in matter, provide a testing ground for determining the depth from which the recorded photons arise. We considered the $\mathrm{K}_{\alpha} / \mathrm{K}_{\beta}$ (or $\mathrm{L}_{\alpha} / \mathrm{L}_{\beta}$, depending on 
the studied element) relative intensity ratio of the representative elements in each pigment, since the attenuation strongly depends on the energy (especially for the energy range involved). When the ratio corresponded (within uncertainties) with predictions from databases, XRF data was then related with the surface layer, otherwise data were associated with deeper layers

\section{Results and Discussion}

Results of the spectroscopic techniques (FORS, XRF) are grouped by the binding media and the materials associated by the color palette of this painting: golden; blue; red; brown; green; flesh tones. Results from the imaging techniques are grouped by following the main areas of the painting composition: the Virgin's face and hands; the crown; and the right-side angel. These images provided the most relevant information of the upper layer version of Mary. The analysis always considered the underlayer versions registered by the radiographic images, which are described in detail in [1], to achieve a correct interpretation of the results provided by the spectroscopic techniques. Imaging results are presented as mosaics, where the different acquired images of one region are contrasted: visible; UV fluorescence; IR pseudo-color (IRPC); spectral angle mapping (SAM); a pseudo-color image composed by the three main PC (PC-1,2,3); principal component 1(PC-1); and three selected different principal components (PC-n).

\subsection{Purísima Concepción: Materials and Painting Technique}

Results from the spectroscopic techniques are divided in a description of the binding media and color palette. In a first approximation, the color palette appears to be simple, with predominance of golden, blue, and red hues. However, the interpretation of the studies applied show a great diversity of materials employed to achieve effects such as brightness, hue, saturation, and even covering power of the paint.

\subsubsection{Binding Media}

FORS SWIR spectra from regions with different colors of the paint are shown in Figure 2, from which it was possible to find common characteristics associated with the binder.

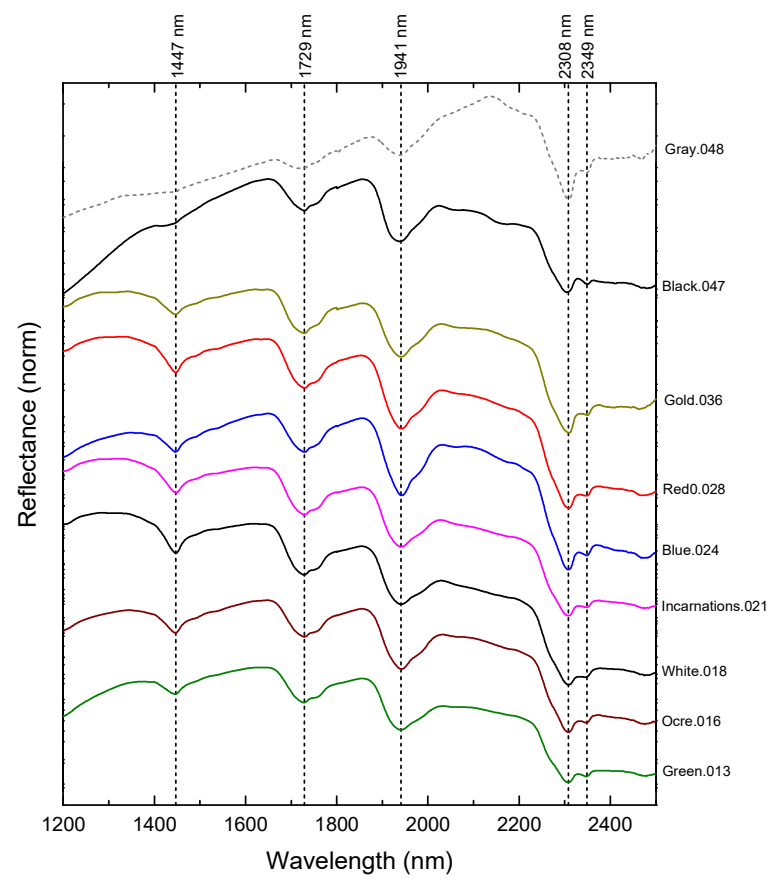

Figure 2. FORS spectra from representative regions corresponding to different colors. Principal features related with binder media are indicated. Spectra corresponding numbers are indicated in Appendix A Figures A1 and A2 general diagram. 
In Figure 2, we can observe spectral features related to lipids on $1729 \mathrm{~nm}$, associated with the first overtone of the stretching mode from the methilenic group $\left[2 v_{a} \mathrm{CH}_{2}\right]$, and combination bands from stretching ( $v_{a}$ asymmetric and $v_{s}$ symmetric) and bending ( $\delta$ ) modes on $2308 \mathrm{~nm},\left[\left(v_{a}+\delta\right) \mathrm{CH}_{2}\right]$, and $2349 \mathrm{~nm}\left[\left(v_{s}+\delta\right) \mathrm{CH}_{2}\right]$. Such characteristics have been noticed in the works by Pérez et al. [7], and Dooley et al. [18]. These absorption bands are common all over the paint, and their presence indicates the knowledge of the drying oil to bind the pigments.

\subsubsection{Color Palette}

Table 1 summarizes the main findings by FORS and XRF spectroscopic techniques of the materials composing the color palette. A detailed description of each pigment is also provided further in this section.

Table 1. Description of the palette by FORS and XRF spectroscopic techniques. ${ }^{a}=$ absorption maximum, ${ }^{b}=$ inflection point, ${ }^{\mathrm{c}}=$ reflectance maximum. A correspondence between FORS and XRF measurements as well as a detailed description of XRF results can be found in Appendix B Tables A1-A6.

\begin{tabular}{|c|c|c|c|c|}
\hline Palette & Region & $\begin{array}{c}\text { Compounds } \\
\text { Identified/Inferred }\end{array}$ & FORS (nm) & XRF \\
\hline Golden & $\begin{array}{c}\text { Virgin Mary: } \\
\text { Trimming } \\
\text { Collar } \\
\text { Christogram } \\
\text { Star Mantle } \\
\text { Imperial crown arche } \\
\text { Imperial crown circlet } \\
\text { Holy Spirit: } \\
\text { Nimbus } \\
\text { Simulated frame } \\
\text { Stellarium } \\
\text { Radiance }\end{array}$ & $\begin{array}{c}\text { Gold Alloy: Au and Cu } \\
\text { Ochre (FeO) + Orpiment } \\
\text { (AsS) }\end{array}$ & $\begin{array}{c}538^{\mathrm{b}} \\
536^{\mathrm{b}} \\
558^{\mathrm{b}} \\
- \\
- \\
- \\
535^{\mathrm{b}} \\
546^{\mathrm{b}} \\
- \\
-\end{array}$ & $\begin{array}{r}\mathrm{Pb}, \mathrm{Cu}, \mathrm{Au}, \mathrm{Hg} \\
\mathrm{Pb}, \mathrm{Au}, \mathrm{Cu}, \mathrm{Ca} \\
- \\
\mathrm{Pb}, \mathrm{Cu}, \mathrm{Au}, \mathrm{Fe} \\
\mathrm{Pb}, \mathrm{Cu}, \mathrm{Fe}, \mathrm{Hg} \\
\mathrm{Pb}, \mathrm{Au}, \mathrm{Cu}, \mathrm{Fe} \\
\mathrm{Pb}, \mathrm{Au}, \mathrm{Cu}, \mathrm{Fe} \\
\mathrm{Pb}, \mathrm{Cu}, \mathrm{Fe}, \mathrm{Au} \\
\mathrm{Pb}, \mathrm{Fe}, \mathrm{Au}, \mathrm{Ca} \\
\mathrm{Pb}, \mathrm{Fe}, \mathrm{Ca}, \mathrm{As}\end{array}$ \\
\hline Blues & $\begin{array}{c}\text { Virgin Mary Mantle } \\
\text { Angel Mantle } \\
\text { Holy Spirit Celestial } \\
\text { Background }\end{array}$ & $\begin{array}{l}\text { Azurite }(\mathrm{CuCaCO}) \\
\text { Azurite }(\mathrm{CuCaCO}) \\
\text { Indigo }\end{array}$ & $\begin{array}{c}465^{\mathrm{c}}, 646^{\mathrm{a}}, 1000^{\mathrm{b}}, 1496^{\mathrm{a}}, \\
2289^{\mathrm{a}}, 2352^{\mathrm{a}}, 483^{\mathrm{c}}, 645^{\mathrm{a}}, \\
1003^{\mathrm{b}}, 1496^{\mathrm{a}}, 2289^{\mathrm{a}}, 2352^{\mathrm{a}} \\
784^{\mathrm{b}}\end{array}$ & $\begin{array}{l}\mathrm{Pb}, \mathrm{Ca}, \mathrm{Cu}, \mathrm{As} \\
\mathrm{Pb}, \mathrm{As}, \mathrm{Ca}, \mathrm{Cu} \\
\mathrm{Pb}, \mathrm{Ca}, \mathrm{As}\end{array}$ \\
\hline Reds & $\begin{array}{l}\text { Virgin Mary: } \\
\text { Lips } \\
\text { Sleeve } \\
\text { Corona }\end{array}$ & Vermillion (HgS) & $\begin{array}{l}594^{\mathrm{b}} \\
596^{\mathrm{b}} \\
594^{\mathrm{b}}\end{array}$ & $\begin{array}{l}\mathrm{Pb}, \mathrm{Hg}, \mathrm{Ca}, \mathrm{Fe} \\
\mathrm{Hg}, \mathrm{Pb}, \mathrm{Fe}, \mathrm{Ca} \\
\mathrm{Pb}, \mathrm{Hg}, \mathrm{Cu}, \mathrm{Fe}\end{array}$ \\
\hline Brownish & $\begin{array}{c}\text { Virgin Mary: } \\
\text { Hair } \\
\text { Crown } \\
\text { Angel: } \\
\text { Hair } \\
\text { Eye }\end{array}$ & $\begin{array}{c}\text { Iron Oxide, Orpiment (AsS) } \\
\text { Iron Oxide, Pb-Sn Yellow } \\
\text { Iron Oxide } \\
\text { Iron Oxide, } \mathrm{Pb}-\mathrm{Sn} \text { Yellow }\end{array}$ & $\begin{array}{c}578^{\mathrm{b}}, 718^{\mathrm{b}}, 831^{\mathrm{a}} \\
- \\
567^{\mathrm{b}}, 720^{\mathrm{b}}, 832^{\mathrm{a}} \\
-\end{array}$ & $\begin{array}{c}\mathrm{Pb}, \mathrm{Fe}, \mathrm{Ca}, \mathrm{Cu}, \mathrm{As} \\
\mathrm{Pb}, \mathrm{Cu}, \mathrm{Fe}, \mathrm{Ca}, \mathrm{Hg}, \mathrm{Sn} \\
- \\
\mathrm{Pb}, \mathrm{Fe}, \mathrm{Hg}, \mathrm{Ca}\end{array}$ \\
\hline Greens & $\begin{array}{c}\text { Virgin Mary Emerald } \\
\text { Palm } \\
\text { Lily }\end{array}$ & Copper Resinate & $\begin{array}{c}584^{\mathrm{c}}, 712^{\mathrm{a}} \\
704^{\mathrm{a}} \\
708^{\mathrm{a}}\end{array}$ & $\begin{array}{l}\mathrm{Pb}, \mathrm{Cu}, \mathrm{Au}, \mathrm{Fe} \\
\mathrm{Pb}, \mathrm{As}, \mathrm{Ca}, \mathrm{Fe} \\
\mathrm{Pb}, \mathrm{As}, \mathrm{Cu}, \mathrm{Fe}\end{array}$ \\
\hline Flesh tones & $\begin{array}{c}\text { Virgin Mary } \\
\text { Angel } \\
\text { Cherub }\end{array}$ & $\begin{array}{l}\text { Vermillion }(\mathrm{HgS})+\text { Lead } \\
\text { White + Azurite }\end{array}$ & $585^{\mathrm{b}}, 1204^{\mathrm{a}}, 1447^{\mathrm{a}}$ & $\begin{array}{l}\mathrm{Pb}, \mathrm{Ca}, \mathrm{Hg}, \mathrm{Fe} \\
\mathrm{Pb}, \mathrm{Ca}, \mathrm{Hg}, \mathrm{Fe} \\
\mathrm{Pb}, \mathrm{Ca}, \mathrm{Hg}, \mathrm{Fe}\end{array}$ \\
\hline
\end{tabular}

The gilding strategies: In the Purísima Concepción, golden regions are present in Mary's apparel, her jewelry, in the stellarium, radiance, and in the painting's frame, with different shades and finishes. The interpretation of the XRF spectra (Figure 3) of the golden regions indicate the presence of $\mathrm{Pb}, \mathrm{Au}, \mathrm{Cu}, \mathrm{Fe}, \mathrm{Ca}, \mathrm{Sn}$, and As. These elements are, in turn, associated with the presence of various pictorial materials. For the gilding, a gold alloy, mainly composed of $\mathrm{Au}$ and $\mathrm{Cu}$ with a significant presence of $\mathrm{Pb}$, commonly associated with lead white $\left(2 \mathrm{PbCO}_{3} \mathrm{~Pb}(\mathrm{OH})_{2}\right)$, e.g., in the trimming, stellarium, crown, and frame. The presence of $\mathrm{Fe}$ is due to the use of brown layers for shadows. These two elements (Fe and $\mathrm{Pb}$ ) are present in a higher proportion in the broad golden lights on the upper part of the painting. The spectra also present an associated signal of Sn, probably related to the tin lead yellow present in the jewelry highlights. The As signal and a noticeably intense 
enhancement in the region where the $S$ signal is expected provide evidence that orpiment $\left(\mathrm{As}_{2} \mathrm{~S}_{3}\right)$ could be present in the earrings and radiance of the Virgin Mary.

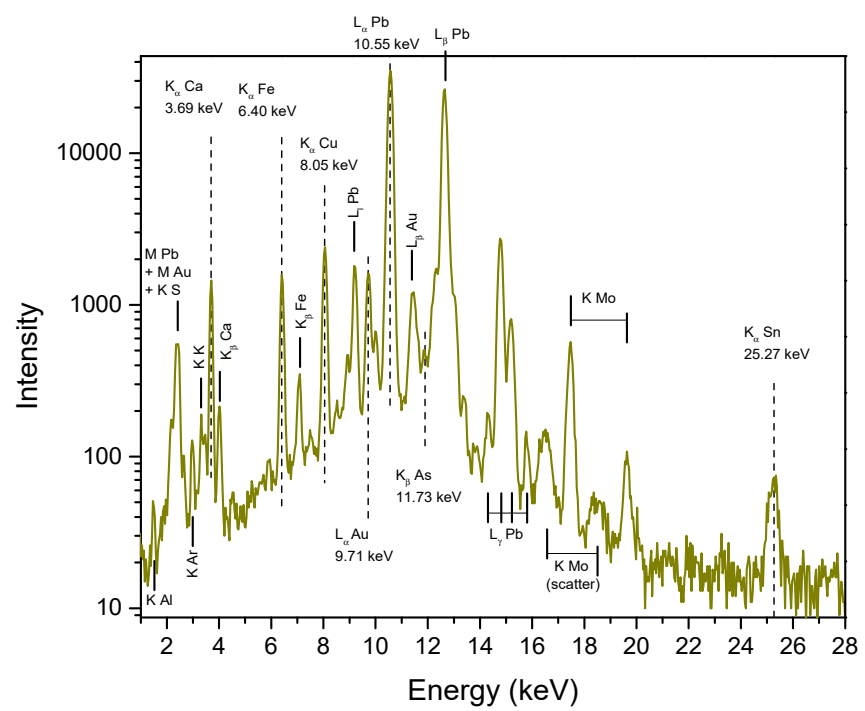

Figure 3. Representative XRF spectrum of a golden region around the crown (XRF.30). See the Appendix A general diagram for details on the acquisition location.

Likewise, representative FORS spectra of the golden regions are presented in Figure 4, where their main characteristics correspond to inflection points between $535 \mathrm{~nm}$ and $590 \mathrm{~nm}$. In metals such as gold, radiation absorption in the visible region is mainly due to processes that involve free electrons.

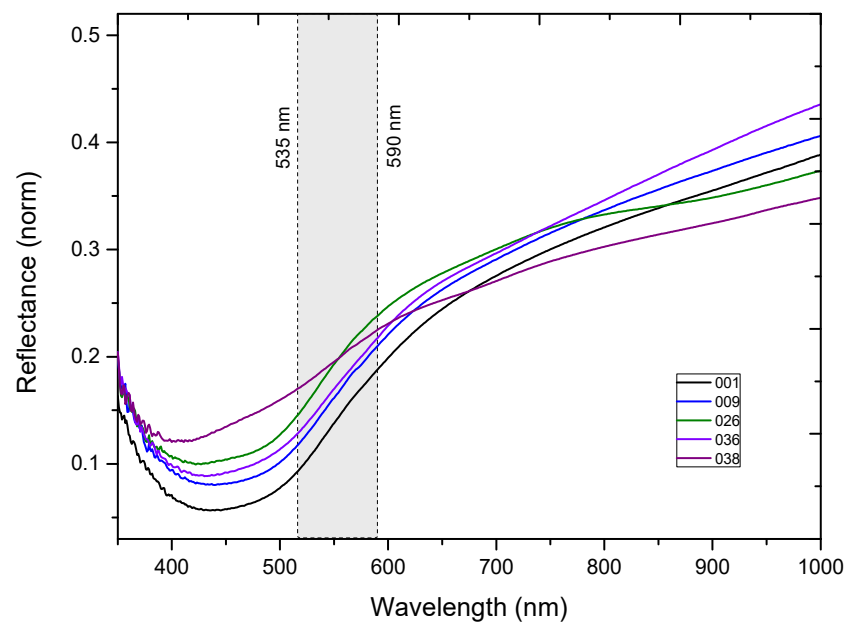

Figure 4. FORS representative spectra from golden regions. Inflection points between $535 \mathrm{~nm}$ and $590 \mathrm{~nm}$ are indicated. Spectra corresponding numbers are indicated in the Appendix A general diagram.

The gilding technique in this painting consisted of flakes ground to a powder, then mixed in oil. Lead white was used to increase the covering power and density of the pictorial layer. The earrings and radiance were made with orpiment, and due to its characteristic tone, saturation, and brightness which makes it look like a precious metal, as well as its ease of handling, plasticity and economy, it replaced the use of gold in certain areas.

In contrast, the simulated frame was created with a golden and matte surface applied with a flat brush, whereas organic figures such as shells and tendrils are highlighted by a brownish shade applied with a round brush. In Novo-Hispanic works from the second half of the 17th century, simulated frames were recurring resources used by artists [19] due to 
an economic limitation, as it was necessary to provide a frame for the works, and bespoke frameworks may have been out of budget, or perhaps the painting of a frame was used to dignify the artistic content.

Gold, an incorruptible and shiny-looking material, has been related to the solar, the igneous, and the divine over time, in addition to its aesthetic and theological metaphors that have added to the notions of prestige and wealth of the precious metal with economic value [20]. The difference between the materials identified to produce the golden effect of the jewels and the Virgin's crown, radiance, and the frame accounts for the knowledge about their properties, their cost, and possibly their existence in the market. The decorum, ornament, and splendor as an object for the liturgy, shows in the gold dust applied in the frame and trimmings, a consideration of distinction of power, luxury, and the elite, entrusted to the master workshop.

Shades of blue: Blue tones are in the second hierarchy of this painting. Even though different shades are registered for the mantle of the Virgin, the cloth of the right angel, the celestial background of the Holy Spirit, and the insular sea in the background, our results by imaging techniques, and by XRF and FORS spectroscopic techniques, indicate the use of only two pigments (see Figure 5 for XRF results), and also provide their distribution throughout the painting. Spectroscopic elemental analysis revealed the use of a $\mathrm{Cu}$ rich pigment in the blue regions of the Virgin's mantle and the clothing of the right angel, which was identified as azurite- $\mathrm{Cu}_{3}\left(\mathrm{CO}_{3}\right)_{2}(\mathrm{OH})_{2}$-from its characteristic bands $(646 \mathrm{~nm}$, $1496 \mathrm{~nm}, 2289 \mathrm{~nm}$ and $2352 \mathrm{~nm}$, see references [18,21]) in the FORS spectra (see Figure 6). In the region of the Holy Spirit, the absorption peaks in these spectra are between $645 \mathrm{~nm}$ and $707 \mathrm{~nm}$, and the shift in absorption peaks could be related to bathochromic effect caused by the mixing of pigments. With precision, the $660 \mathrm{~nm}$ peak is reported as the main characteristic of indigo [21]. Regarding the blue hues, the material distinction between a mineral and lake-pigment was researched in paintings of Virgin Mary from the 16th and 17 th centuries [22]. The predominant color in the mantles is azurite, and indigo for the backgrounds. In this case, the anonymous painter continues with this knowledge and significance, proposing not only a common solution, but also the knowledge of treatise, and the cost of these materials.

Traces of mercury for red areas: XRF spectra from the red areas revealed the use of a $\mathrm{Hg}$ rich pigment (Figure 7). Likewise, FORS reflectance spectra from these red areas show an inflection point around $594 \mathrm{~nm}$ as the main characteristic (Figure 8), confirming the presence of vermillion $(\mathrm{HgS})$ as the main pigment to give this hue. Additionally, absorption characteristics were identified at $1198 \mathrm{~nm}$ and $1447 \mathrm{~nm}$, associated with the first overtone of the hydroxyl group [2 $2 \mathrm{OH}]$ in the lead white pigment, as reported in Picollo et al. [23].

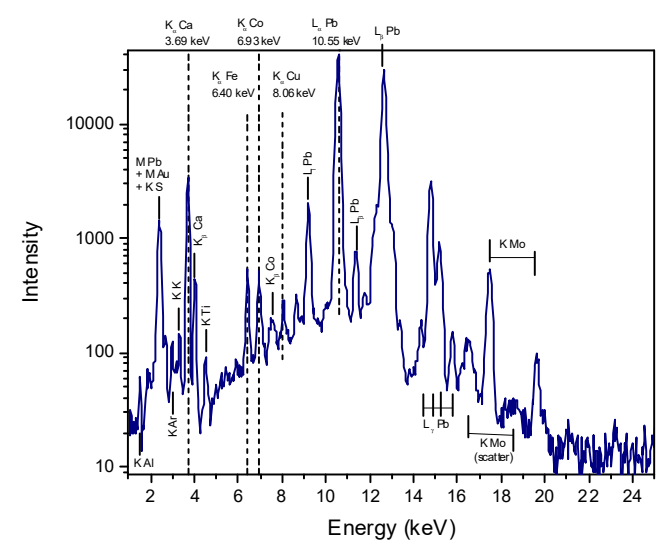

(a)

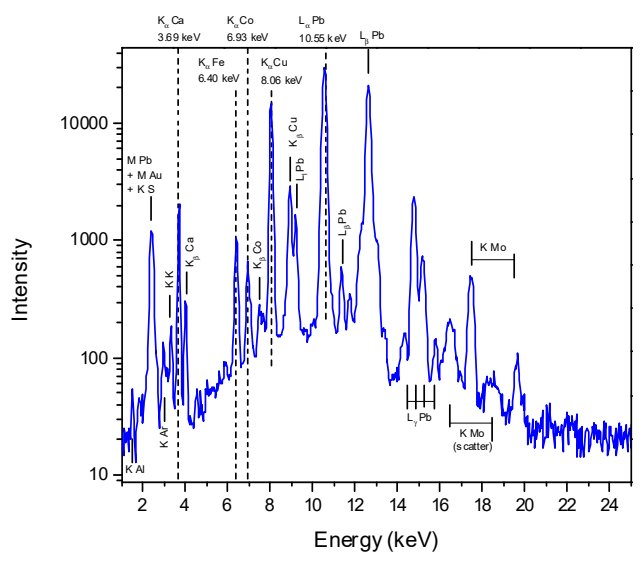

(b)

Figure 5. (a) representative spectrum (XRF.24) from Holy Spirit region, (b) representative spectrum (XRF.55) from Virgin's mantle region. Their corresponding locations are detailed in Appendix A general diagram. 
Green tones: A single pigment was identified in all the green areas from this painting, found in the representation of emeralds in the imperial crown, and the stems and leaves of the palm and the lily in the lower area. FORS spectra for this pigment have a reflectance maximum between $554 \mathrm{~nm}$ and $584 \mathrm{~nm}$, and absorption bands between $696 \mathrm{~nm}$ and $717 \mathrm{~nm}$ (Figure 9), which together with the IR signature (Figure 10) allowed to identify the pigment as copper resinate [7]. XRF spectra (Figure 11) confirm the presence of $\mathrm{Cu}$ in the green areas, but also presents $\mathrm{Pb}, \mathrm{Hg}$ and $\mathrm{Fe}$, and vermilion or iron earth to change the saturation of the jewel and the volume from the shadows. Finally, the presence of Au in the green emeralds from the crown may indicate that these were painted over the golden region.

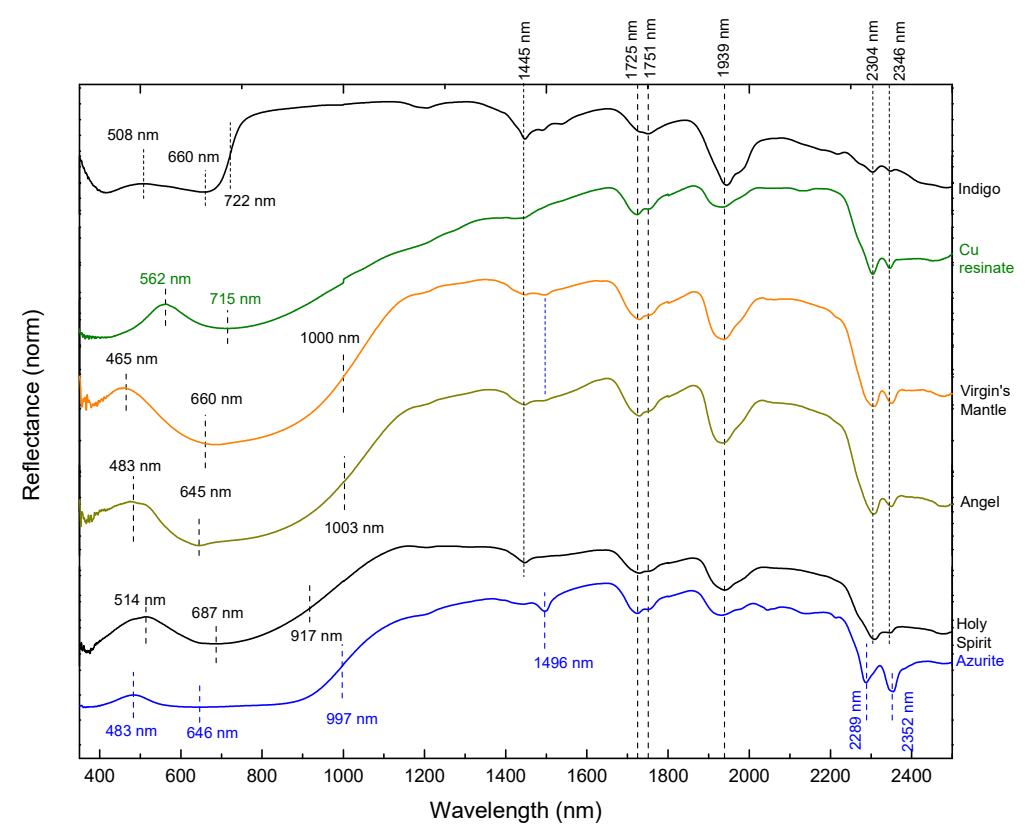

Figure 6. FORS spectra from blue regions: Virgin's mantle, angel's mantle, and Holy Spirit blue background. Vis-NIR reflectance features are indicated. Reference materials (indigo, Cu resinate, and azurite) are included for comparison.

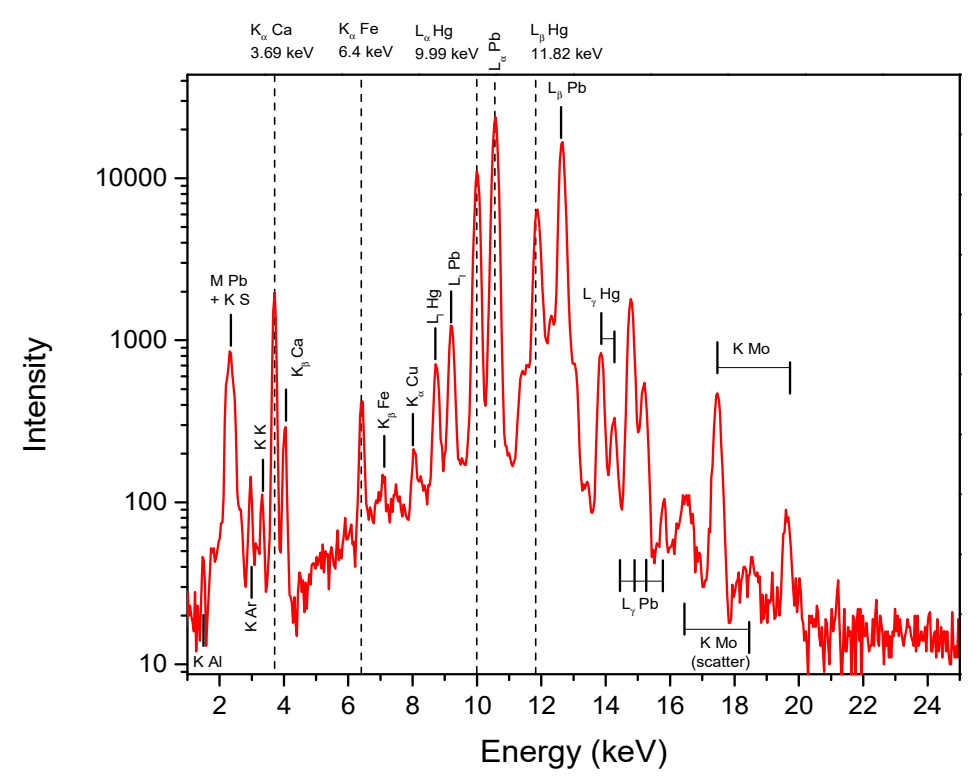

Figure 7. Representative spectrum (XRF.73) from red regions. Features related with $\mathrm{Hg}$ are indicated. Spectra detailed location can be seen in Appendix A general diagram. 


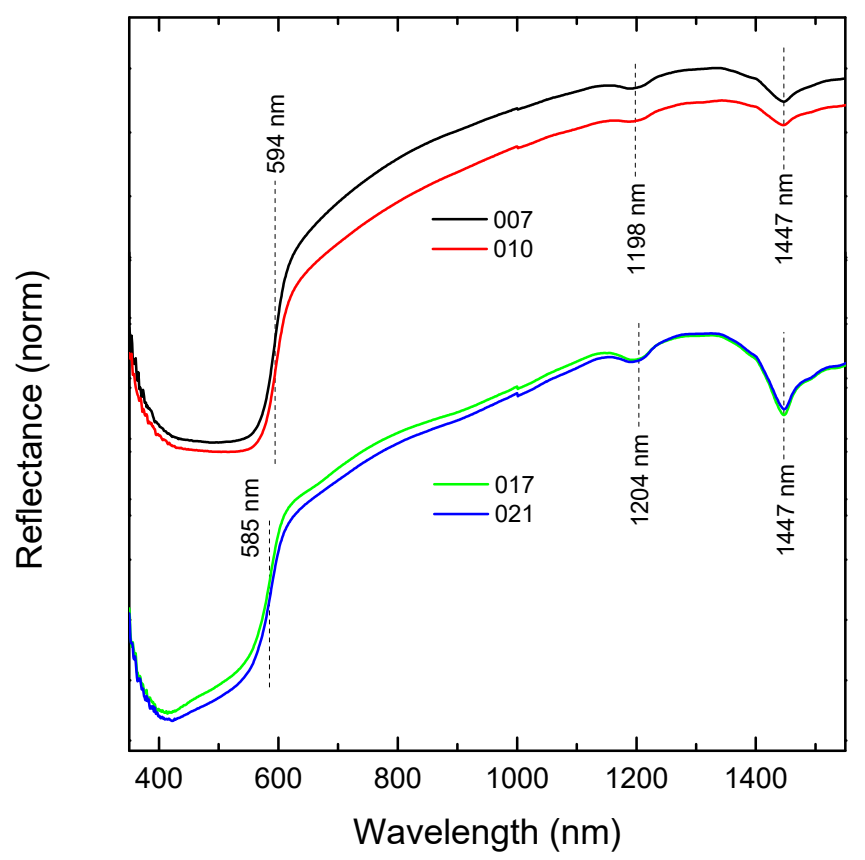

Figure 8. (TOP) FORS representative spectra from red regions (FORS.007 and FORS.010), inflection point near $594 \mathrm{~nm}$ related with vermilion $(\mathrm{HgS})$ is indicated. (BOTTOM) (FORS representative spectra from incarnation regions (FORS.017 and FORS.021). Features near 1198 nm and 1447 nm, related with lead white are indicated. Spectra corresponding locations are indicated in Appendix A general diagram.

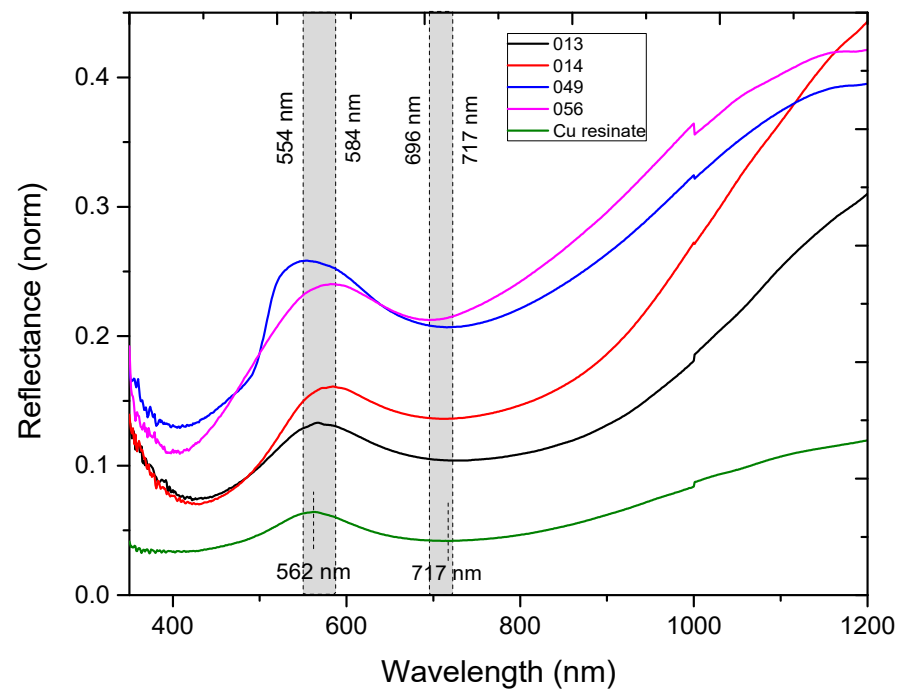

Figure 9. FORS representative spectra from green regions. Reflectance maxima were observed between $554 \mathrm{~nm}$ and $584 \mathrm{~nm}$, and absorption bands between $696 \mathrm{~nm}$ and $717 \mathrm{~nm}$. Copper resinate reflectance spectrum was included for comparison. Numbers corresponding to spectra are shown in Appendix A general diagram.

Brown: Brown areas in the painting were associated with the presence of $\mathrm{Fe}$, as determined by XRF, possibly related with the use of burnt earth for the shadows, and are of a uniform hue. Its use in the hair and pupils of Mary and the angels were defined by brushstrokes at the tip of a round and fine brush, whereas for the volume of the cloths, the jewelry, or the crown, a flat brush was applied. From the interpretation by XRF spectroscopy, the abundant presence of $\mathrm{Pb}$ indicates the incorporation of white lead in this color layer, probably to provide a greater covering power. 
Flesh tones: To generate the flesh tones of Mary and the angels, XRF identified the incorporation in a higher proportion of white lead $(\mathrm{Pb})$, vermilion $(\mathrm{Hg})$, azurite $(\mathrm{Cu})$, and calcine natural iron oxide (Fe) (Figure 12). This mixture was made on a palette and applied with a fine brush tip. Vermilion was used for the touches of blush on the cheeks, whereas the volume of the face from lights used an abundance of lead white, and the shadows used natural sienna.

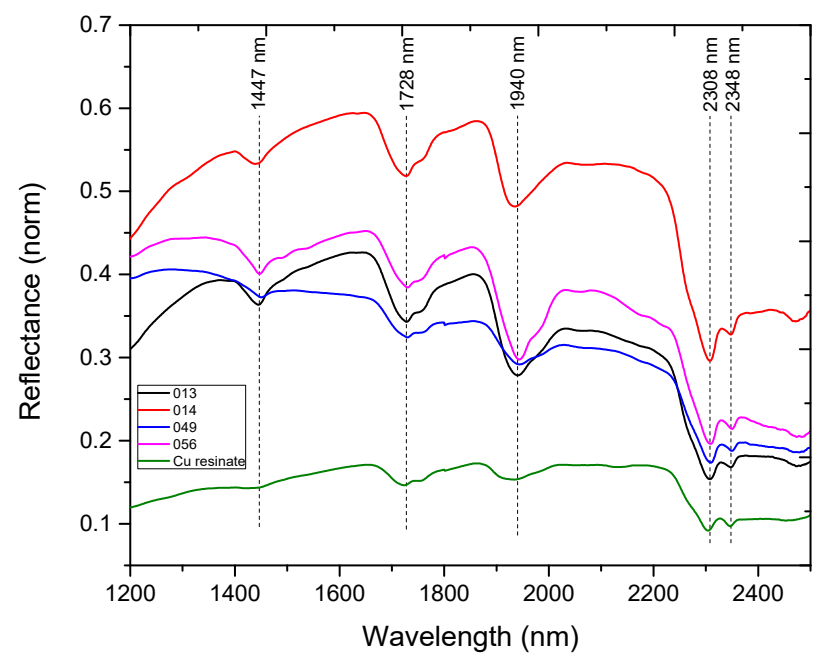

Figure 10. FORS spectra from green regions. Spectral features are indicated and compared with copper resinate reference. Spectra numbers of corresponding regions are shown in Appendix A general diagram.

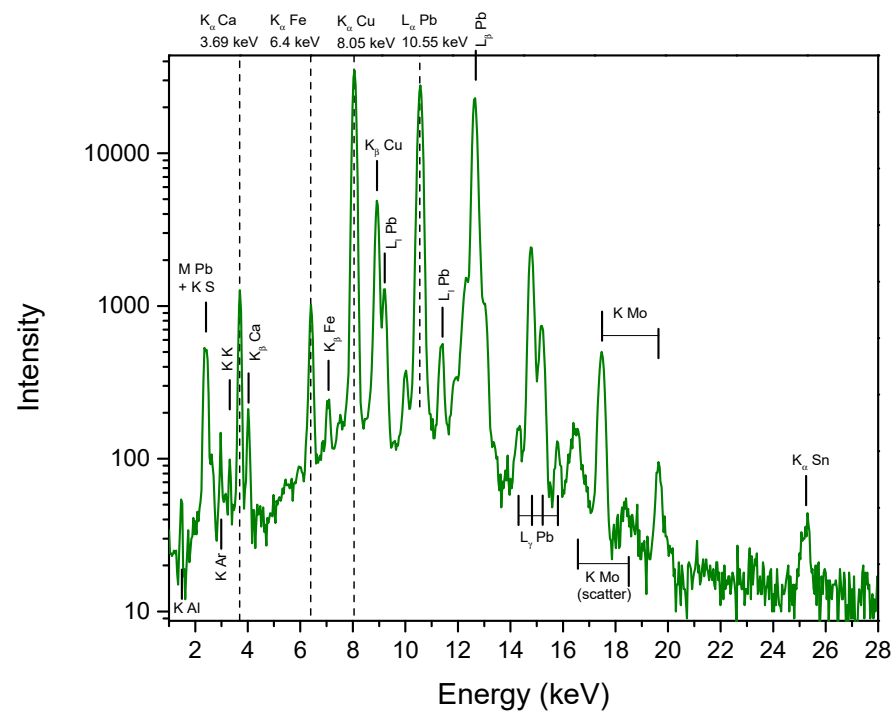

Figure 11. Representative spectrum (XRF.029) from green regions, features related with $\mathrm{Ca}, \mathrm{Fe}$, and $\mathrm{Cu}$ are indicated. Spectrum corresponding location is indicated in Appendix A general diagram.

\subsection{The Virgin Mary: Changes of View and Composition by Imaging Techniques}

The comparison of the resulting images from the different techniques allowed the identification of changes in the Virgin Mary, the angels, and the iconographic elements that accompany them, and made it possible to identify restoration areas more easily in the artwork, which were not noticeable due to the yellowish varnish and the absence of documentation on the restoration carried out in the painting. Table 2 gathers the characteristics observed from the different imaging techniques for the three areas analyzed (Figures 13-16), where visible image, IRPC, UV image, and PC stand out. 


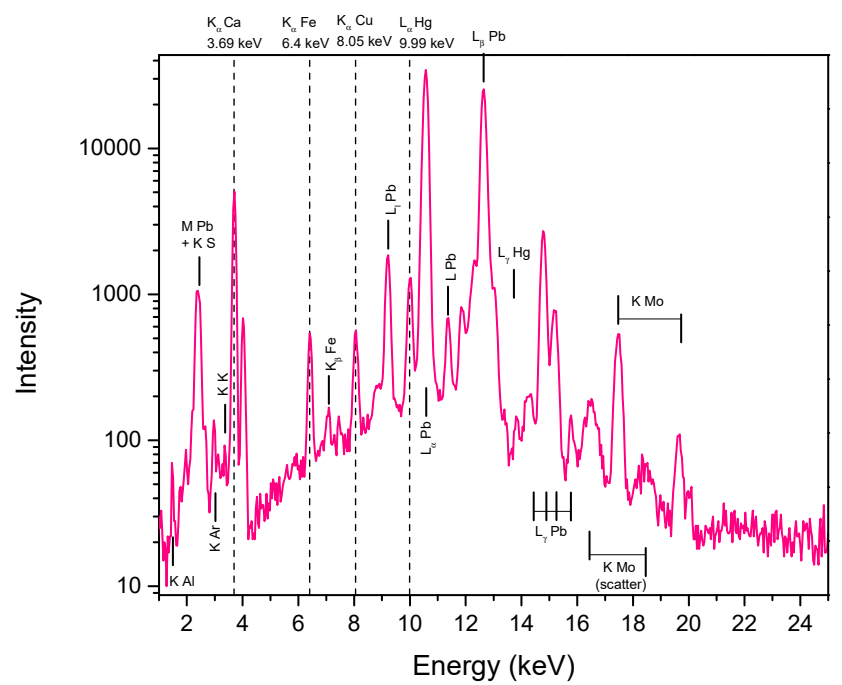

Figure 12. Representative spectrum (XRF.041) from flesh tones, features related with $\mathrm{Ca}, \mathrm{Fe}, \mathrm{Cu}$, and $\mathrm{Hg}$ are indicated, associated with the use of vermilion. Spectrum corresponding location is indicated in Appendix A general diagram.
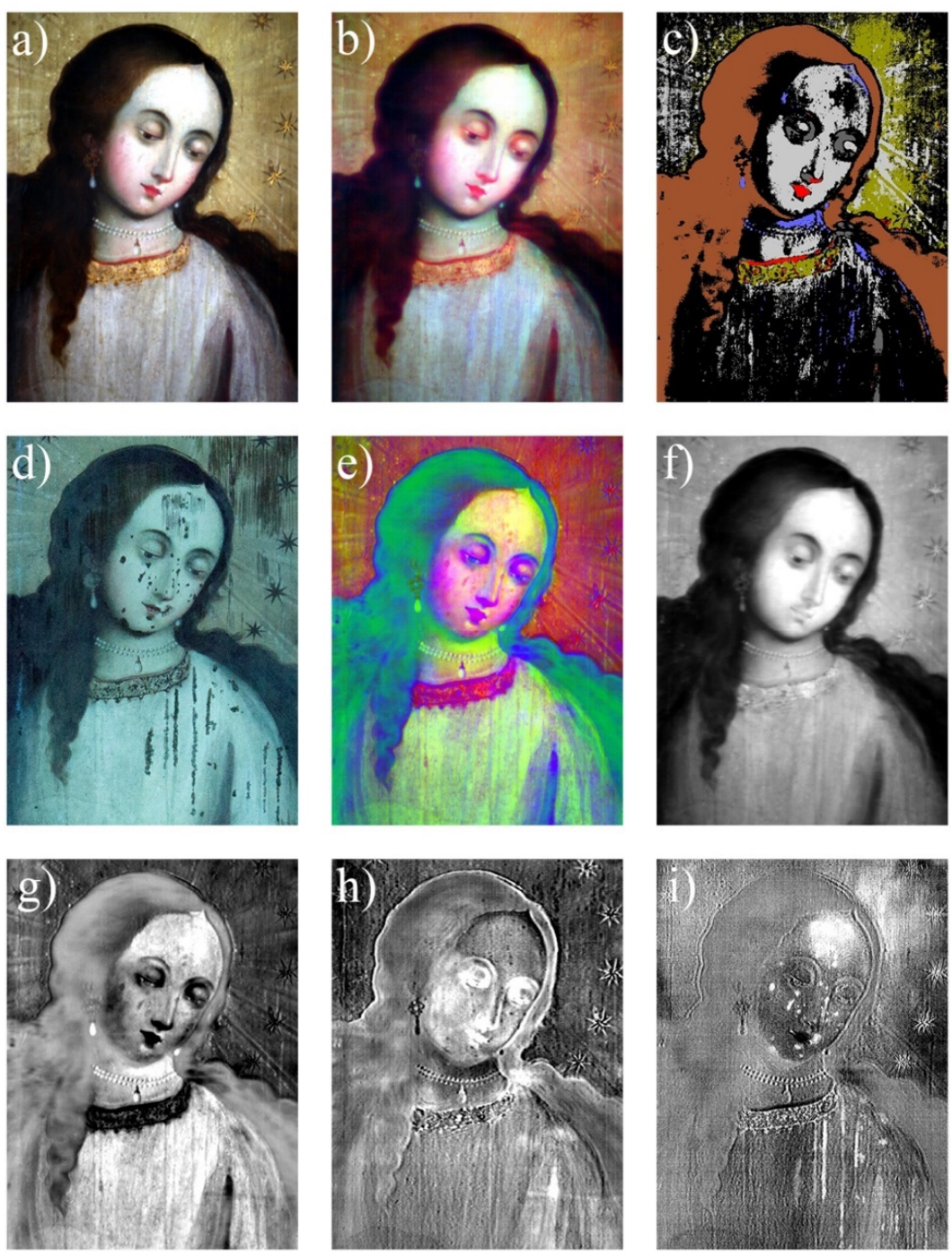

Figure 13. Virgin Mary face region: (a) visible image; (b) pseudo color image; (c) SAM image; (d) UV fluorescence image; (e) RGB-PCA; (f) PC1; (g) PC2; (h) PC3; and (i) PC9. 
Table 2. Results from imaging analysis for the three studied regions in the Purísima Concepción.

\begin{tabular}{|c|c|c|}
\hline Region & Image & Results \\
\hline \multirow{5}{*}{ Virgin Mary, Face (Figure 13) } & (a), (d) & $\begin{array}{l}\text { When comparing the mosaics (a) and (d), we notice the restoration by } \\
\text { vertical lines on the face and the white tunic. }\end{array}$ \\
\hline & (h) & Mosaic (h) highlights the volume of the layers of color in the golden areas. \\
\hline & (a), (e) & $\begin{array}{l}\text { When comparing (a) and (e), the pseudo color image shows that the reddish } \\
\text { tones of the eyelids, cheeks, and tunic present a similar tonality, which } \\
\text { indicates a vermilion distribution. This pigment was identified by XRF and } \\
\text { FORS. }\end{array}$ \\
\hline & (a), (e) & $\begin{array}{l}\text { Image (e) allows us to appreciate the distribution of the gilding applied in } \\
\text { the jewels, trimmings, and Stellarium. }\end{array}$ \\
\hline & (a), (i) & $\begin{array}{l}\text { By comparing (a) and (i), we can observe the restoration areas on the face } \\
\text { corresponding with white tones. It also highlights the texture of the } \\
\text { Stellarium fillings, the pearl necklace, and trimmings for the tunic. }\end{array}$ \\
\hline \multirow[t]{3}{*}{$\begin{array}{l}\text { Virgin Mary, Hands } \\
\quad \text { (Figure 14) }\end{array}$} & $(\mathrm{a}),(\mathrm{b}),(\mathrm{e})$ & $\begin{array}{l}\text { Images (a), (b), and (e) make it possible to compare the distribution of the } \\
\text { material applied in the gilding of the trimmings, the Christogram, and the } \\
\text { stars of the mantle. From XRF, the presence of } \mathrm{Au} \text { and } \mathrm{Cu} \text { indicate a gold } \\
\text { alloy, such as in the quadrant of Mary's face, whereas the stars of the mantle } \\
\text { were made by a pigment with a high content of } \mathrm{Pb} \text { and } \mathrm{Sn} \text {. }\end{array}$ \\
\hline & (a), (d) & Comparing (a) and (d), we can observe restoration areas. \\
\hline & (a), (i) & $\begin{array}{l}\text { Between (a) and (i), we could see the profile of a version of the Virgin Mary, } \\
\text { an underlying composition painted in a previous century. }\end{array}$ \\
\hline \multirow[t]{2}{*}{ Imperial Crown (Figure 15) } & (a), (b) & $\begin{array}{l}\text { Images (a) and (b) exhibit different contributions of the materials used in the } \\
\text { golden, reddish, bluish, and green tones. First, the application of gilding in } \\
\text { the lower area of the crown and Stellarium present a similar composition of } \\
\mathrm{Au} \text { and } \mathrm{Cu} \text {, whereas the upper area presents an opaque tonality due to the } \\
\text { use of an earth shade. } \\
\text { The reddish bonnet of the crown, in addition to the incarnation of the angels } \\
\text { hands, and the representation of rubies, present the same yellow hue based } \\
\text { on vermilion. } \\
\text { Blush is distinguished by a reddish hue for the celestial background of the } \\
\text { Holy Spirit, compared to FORS spectroscopic techniques, and this material } \\
\text { indicates the presence, in greater contribution, of a lacquer pigment, such as } \\
\text { indigo. } \\
\text { As for the green, the jewels that represent the emeralds indicate the same } \\
\text { bluish material, whereas the XRF spectroscopy indicates the presence of Cu, } \\
\text { and, in complement with FORS, they help us to confirm the presence of a } \\
\text { copper resinate. }\end{array}$ \\
\hline & $(\mathrm{a}),(\mathrm{d}),(\mathrm{i})$ & $\begin{array}{l}\text { The comparison of Images (a), (d), and (i) allows us to distinguish the } \\
\text { restoration of the background of the painting by means of the Rigatino, which } \\
\text { is vertical and fine brushstrokes applied in the regions with material losses. }\end{array}$ \\
\hline \multirow[t]{2}{*}{ right-Side Angel (Figure 16) } & $(\mathrm{a}),(\mathrm{b}),(\mathrm{d})$ & $\begin{array}{l}\text { In Figures (a) and (b), the distribution of materials with the same behavior } \\
\text { are shown: the reddish tone of vermilion was used in the blush of the cheeks, } \\
\text { lips, and wings of the angels, whereas in the blue tone of the cloth, there is } \\
\text { azurite. }\end{array}$ \\
\hline & (a), (d) & $\begin{array}{l}\text { The restoration of the background by Rigatino is noticeable when comparing } \\
\text { Figures (a) and (d). }\end{array}$ \\
\hline
\end{tabular}



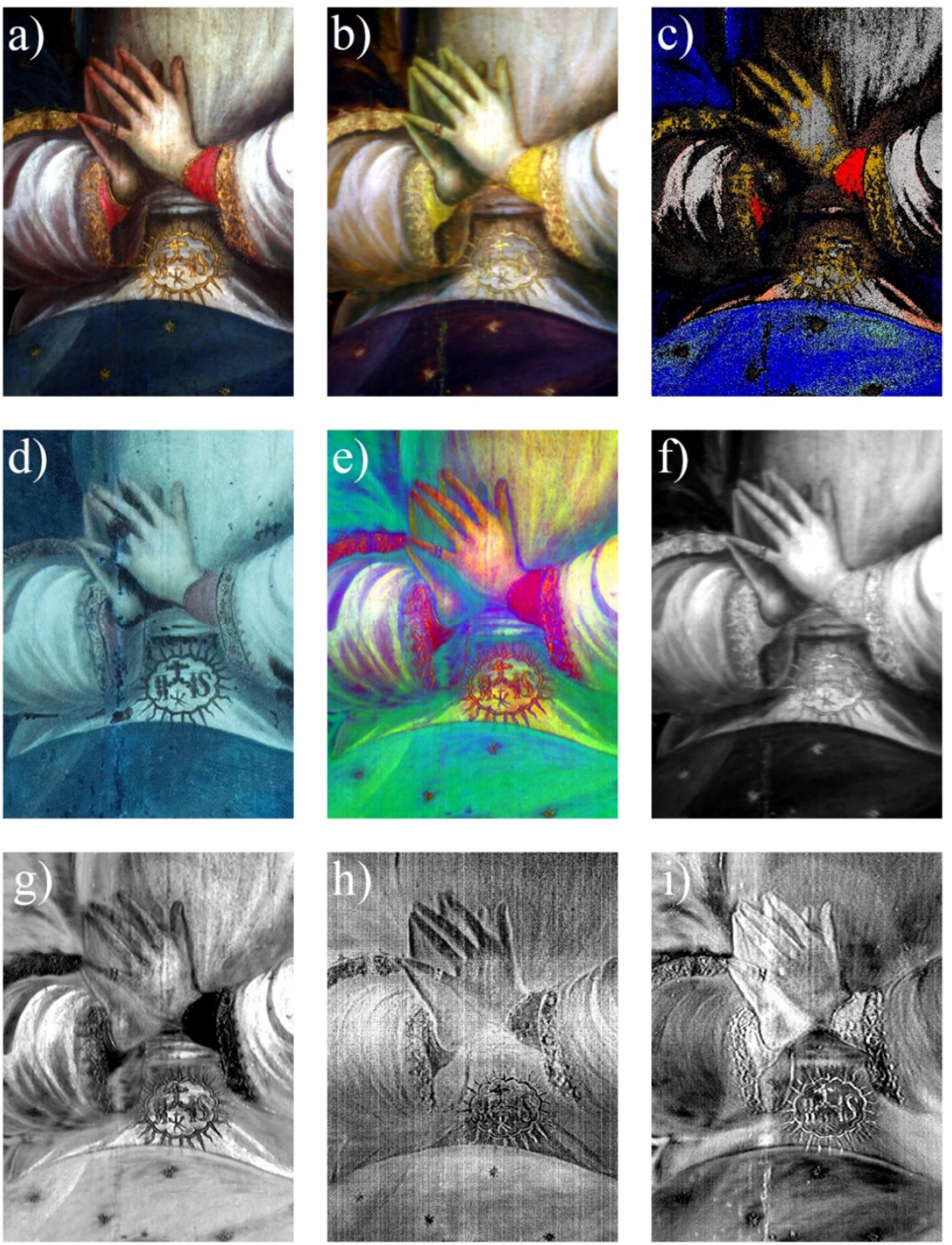

Figure 14. Virgin Mary's hands region: (a) visible image; (b) pseudo color image; (c) SAM image; (d) UV fluorescence image; (e) RGB-PCA; (f) PC1; (g) PC2; (h) PC3; and (i) PC8.
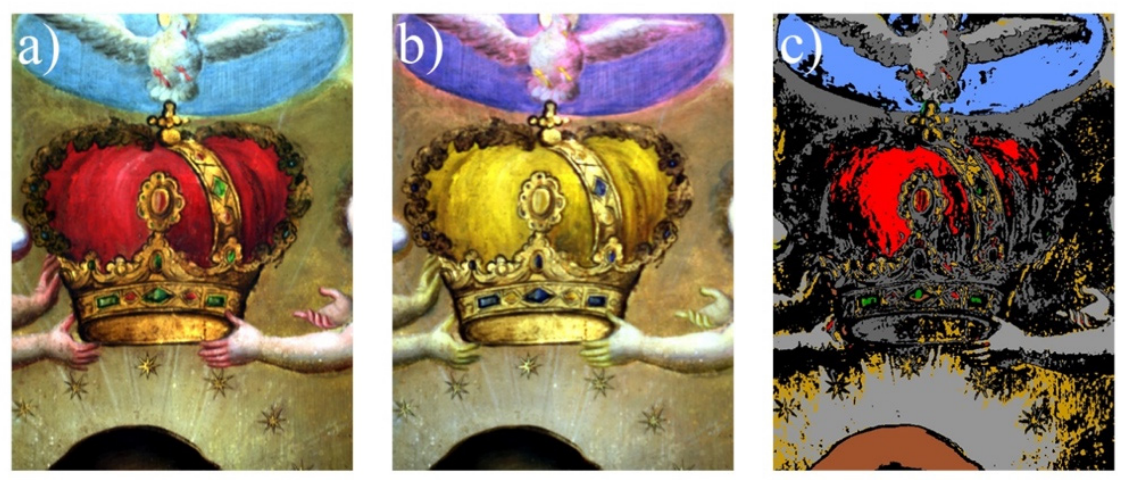

Figure 15. Cont. 

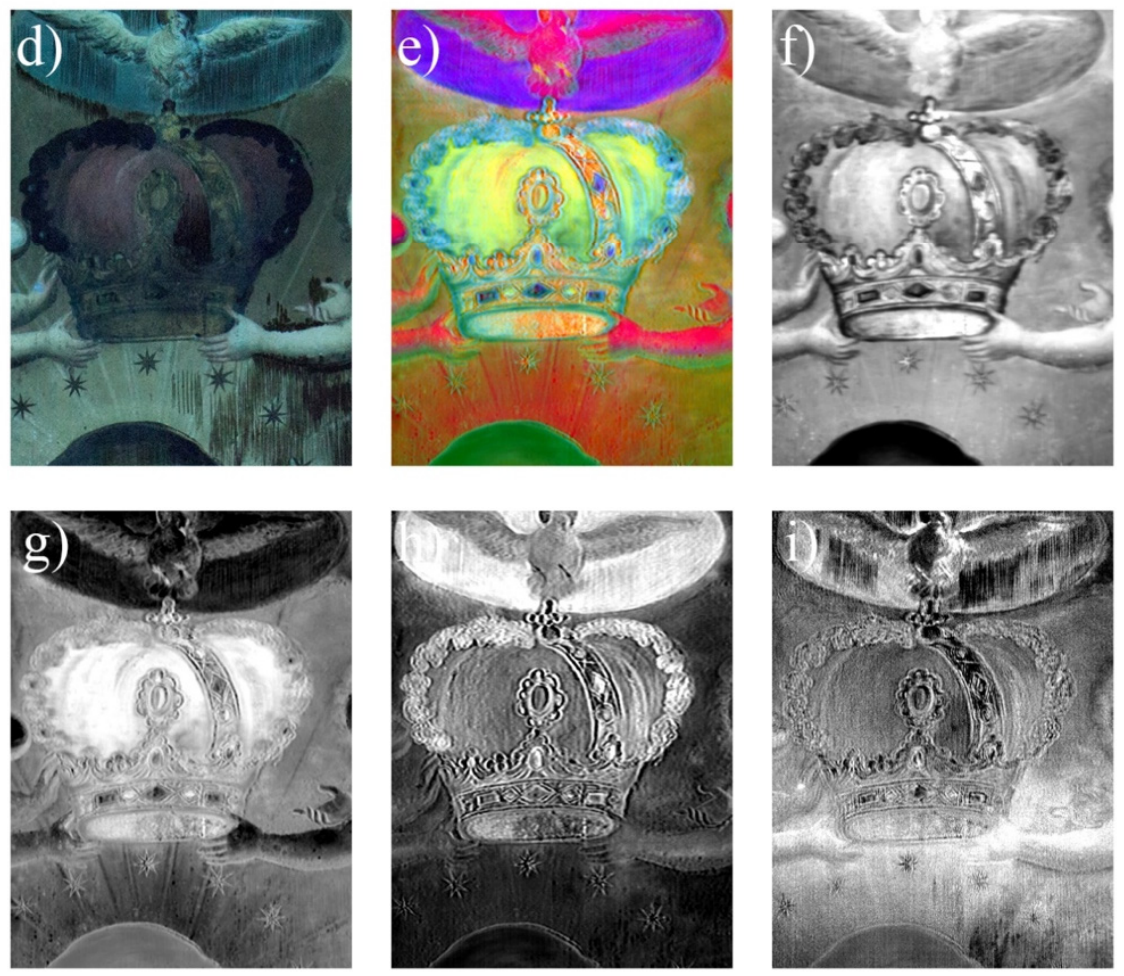

Figure 15. Imperial crown and Holy Spirit region: (a) visible image; (b) pseudo color image; (c) SAM image; (d) UV fluorescence image; (e) RGB-PCA; (f) PC1; (g) PC2; (h) PC3; and (i) PC4.
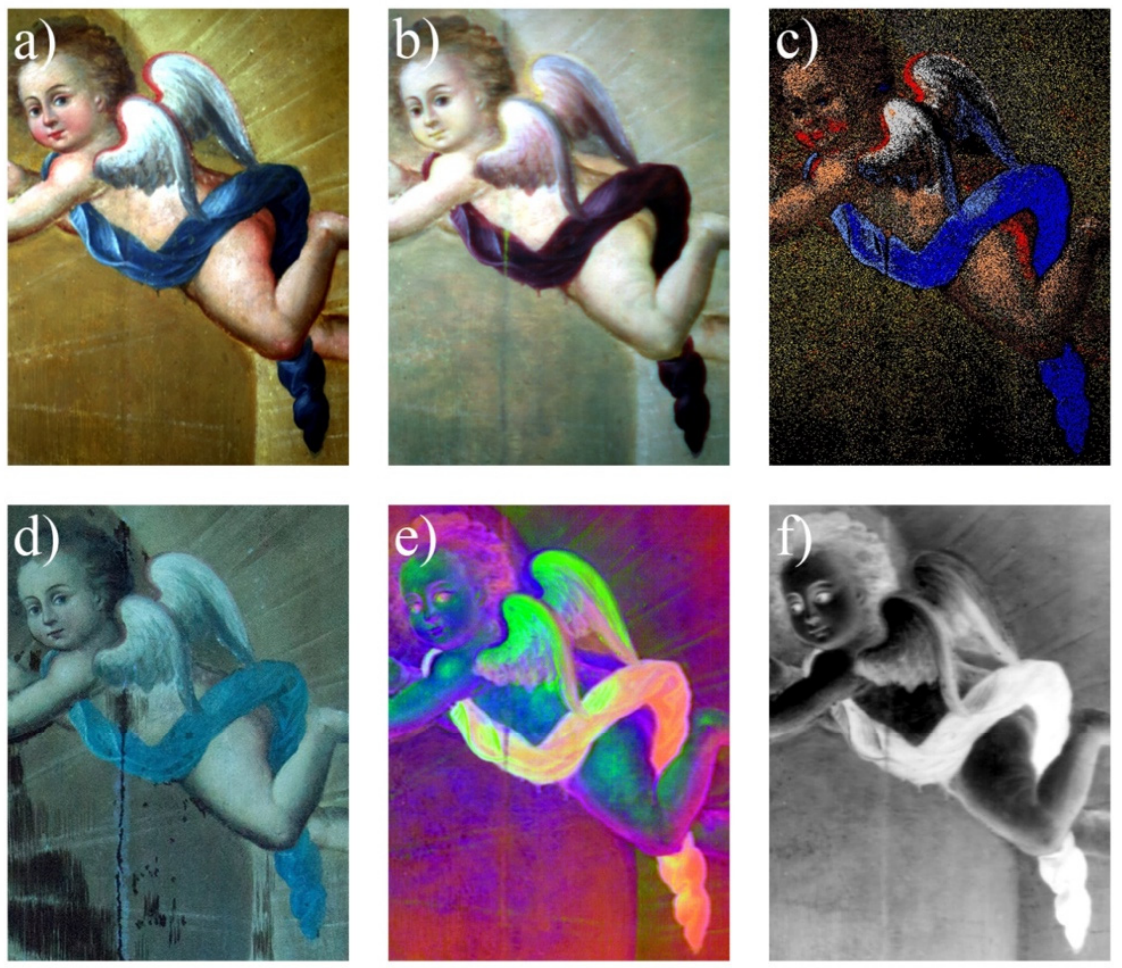

Figure 16. Cont. 

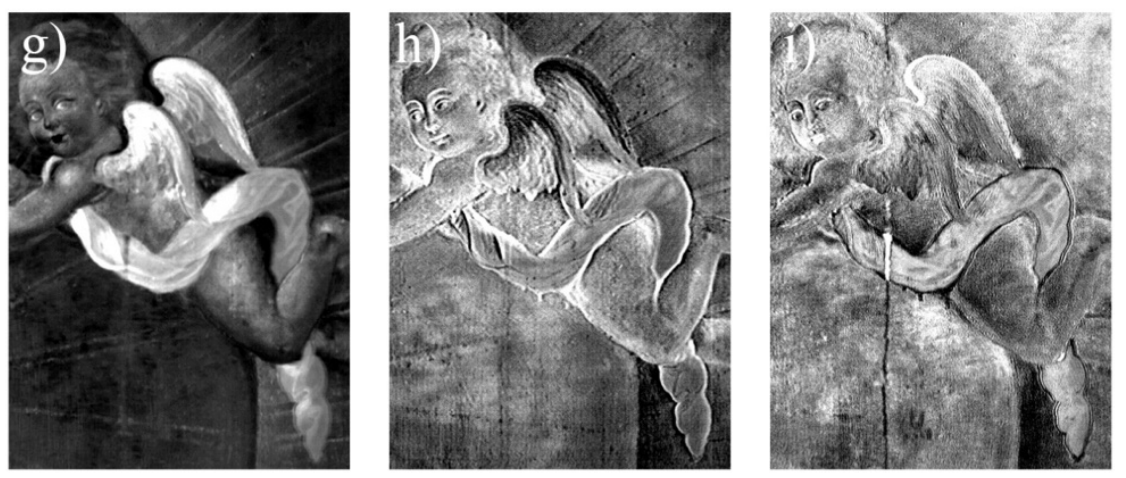

Figure 16. Right-side angel region: (a) visible image; (b) pseudo color image; (c) SAM image; (d) UV fluorescence image; (e) RGB-PCA; (f) PC1; (g) PC2; (h) PC3; and (i) PC8.

\section{Conclusions}

This work provided detailed information on the material composition of the color palette, by means of a combined imaging and spectroscopy method. HSI analysis has proven to be a powerful tool, and it allowed us to describe details on the distribution of the pigments, as well as a description on the manufacture of the painting. It also provided information on the presence of later repairs (consistent with UV imaging analysis), as well as insights on the existence of a previous painting (as was demonstrated by radiography of the painting).

In this artwork, the selection of materials by the artist considered the importance of the represented objects. Golden regions are present with different shades and finishes, and a gold alloy was used for the trimming, stellarium, crown, and frame. Fe was used for brown layers in the shadows. Tin lead yellow is present in jewelry highlights, orpiment in the earrings, and in radiance of the Virgin Mary. Blue tones characterization indicates the use of only two pigments: azurite for the Virgin's mantle and the clothing of the right angel; and indigo for the Holy Spirit region. A single green pigment was found in the painting, located in the representation of emeralds, and the stems and leaves in the palm and the lily in the lower area, which has been identified as copper resinate. Brown areas exhibit the presence of $\mathrm{Fe}$, which is related with the use of burnt earth, used in the hair and pupils of Mary and the angels. Flesh tones of Mary and the angels contain a mixture of white lead, vermilion, azurite, and calcine natural iron oxide.

Results suggest the knowledge and experience of an oil-on-wood painter who possibly still conformed to the conditions of the ordinances and traditions established in the prior two centuries of colonial establishments. For the wood panel, its cut and construction are due to a process of specialized knowledge of carpentry work. However, it would be worthwhile to carry out studies on the cellular structure of the wood, the ring count to identify the selected genus, its possible extraction region, and when the tree was cut, in order to specify the work production system, in terms of the time and use of material resources.

Regarding the color palette, the system of selection and application of materials possibly considered qualities of stability, accessibility, and cost, which makes us think about the knowledge and versatility on the part of the architect to work with the different materials available.

It is also necessary to mention that the non-invasive studies by imaging techniques complemented with FORS and XRF spectroscopic techniques, although they offer high sensitivity and precision, had limitations in interpreting the areas of analysis, due to the complex layer superposition in the painting. The continuity of this study is suggested through the application of invasive techniques by means of a strategic selection of samples, and their eventual analysis by optical and electron microscopy to identify the sequence of their application and distribution, as well as the underlying pictorial campaign. 
Author Contributions: M.P.: Writing-original draft, Methodology, Software, Formal analysis, Investigation. N.C.: Writing-original draft, Project administration, Methodology, Formal analysis, Investigation. J.L.R.-S.: National Laboratory Manager, Funding acquisition, Project administration, Investigation, Writing-review and editing. A.M.: Writing-review and editing, Formal analysis, Investigation. O.G.d.L.: Writing-review and editing, Methodology, Visualization, Investigation. Authors M.P. and N.C. contributed equally to this work and they both should be considered as FIRST AUTHOR. All authors have read and agreed to the published version of the manuscript.

Funding: This research was funded by CONACYT, grants numbers LN315853, LN299076, LN 314846, CB239609 and by DGAPA-PAPIIT grants numbers IN108521 and IT101219.

Institutional Review Board Statement: Not applicable.

Informed Consent Statement: Not applicable.

Data Availability Statement: Not applicable.

Acknowledgments: We express our gratitude to the following individuals and institutions: María del Perpetuo Socorro Villarreal Escárrega, Asuntos Jurídicos INAH; Maria del Carmen Castro, Liliana Giorguli, Irlanda Fragoso, Emmanuel Lara, María Eugenia Marín Benito, Cristina Noguera CNCPCINAH; Antonio Huitrón Santoyo, Josué Alcántara, Centro INAH Estado de México; Armando Rosas, Museo Ex Convento San Agustín Acolman. We acknowledge the technical support of E. Casanova a I. Rangel. M. Pérez and N. Cano acknowledge the support of PNPC scholarship granted by CONACYT.

Conflicts of Interest: The authors declare no conflict of interest. The funders had no role in the design of the study; in the collection, analyses, or interpretation of data; in the writing of the manuscript, or in the decision to publish the results.

\section{Appendix A}

A general description of the acquisition regions and points for the different analysis techniques are presented here.

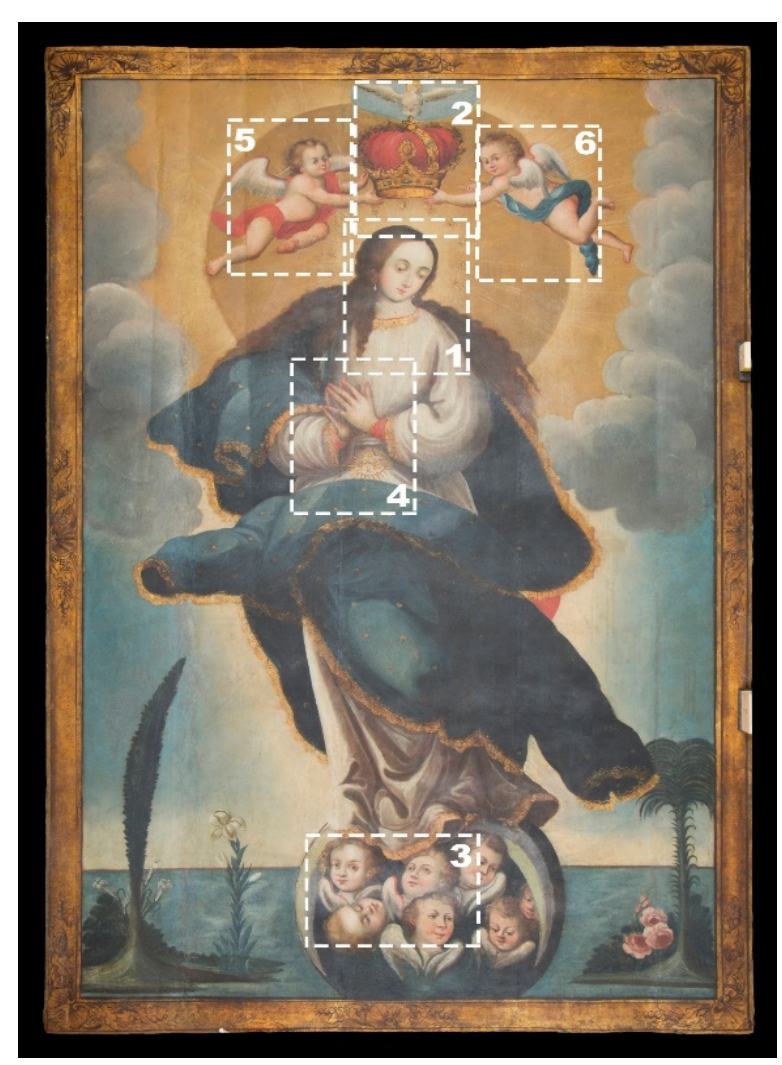

Figure A1. Hyperspectral analysis locations and dimensions. A total of six regions were studied in this research work by HSI technique. 


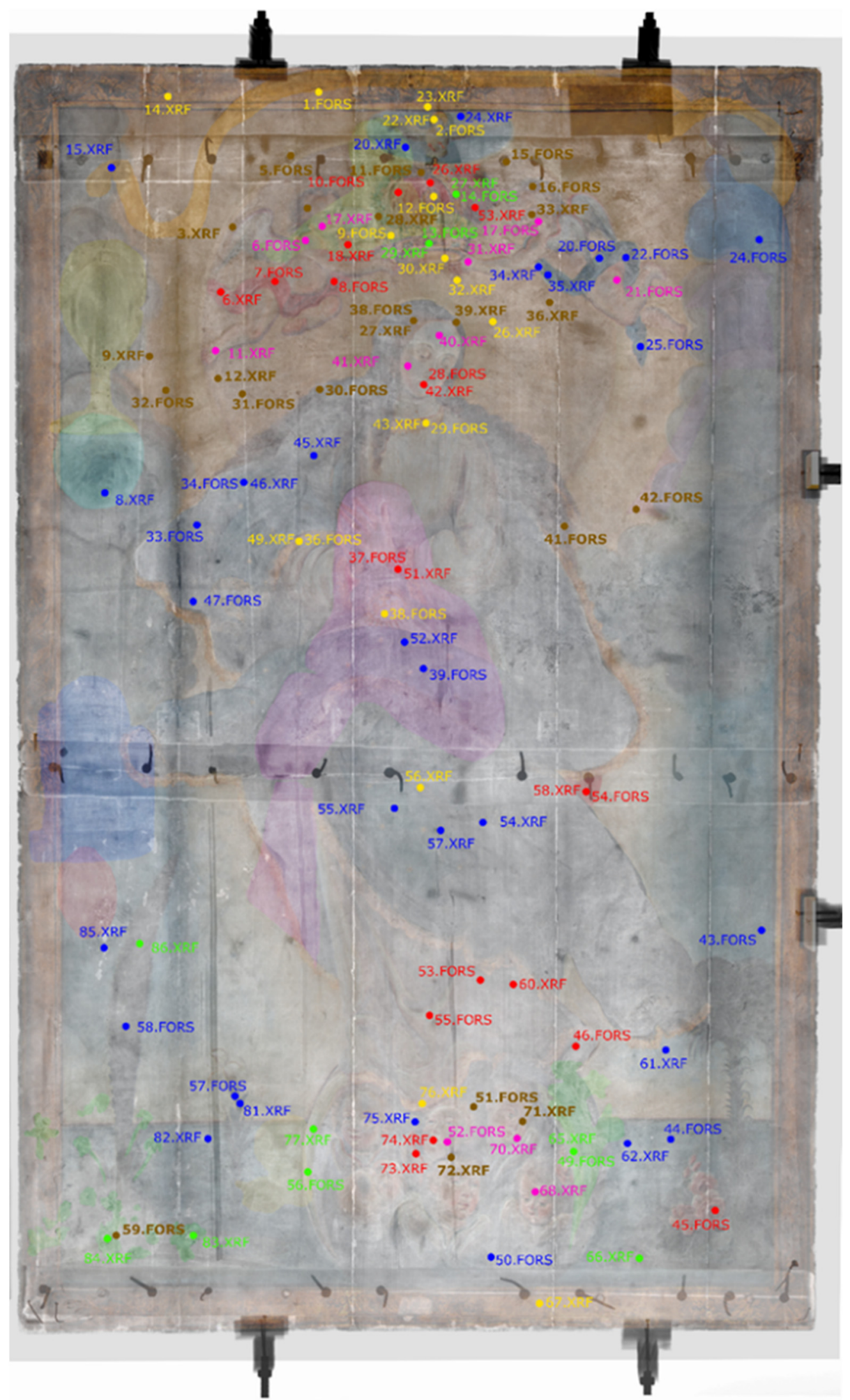

Figure A2. General diagram. Superposition of visible image and radiography image of Purísima Concepción, indicating the acquisition points for XRF (nn.XRF) and FORS (nn.FORS) spectroscopic techniques. Underlying features are highlighted with colors to facilitate the reading of the image. 


\section{Appendix B}

The main findings from spectroscopic techniques are presented in the following tables, grouped by colors. Acquisition region is indicated, as well as ID for XRF and FORS acquisition points. In some cases, both spectroscopic techniques correspond with the same geometric spot, although they have different ID numbers. Elements reported are sorted in descending order by the intensity of their most intense characteristic X-ray line. Each pigment's representative elements are highlighted.

Table A1. Golden.

\begin{tabular}{|c|c|c|c|}
\hline Region & XRF ID & Elements & FORS ID \\
\hline \multicolumn{4}{|l|}{ Virgin Mary } \\
\hline Trimming & 49 & $\mathrm{~Pb}, \mathrm{Cu}, \mathrm{Au}, \mathrm{Hg}, \mathrm{Ca}, \mathrm{Fe}$ & 36 \\
\hline Collar & 43 & $\mathrm{~Pb}, \mathrm{Au}, \mathrm{Cu}, \mathrm{Ca}, \mathrm{Hg}, \mathrm{Fe}$ & 29 \\
\hline Christogram & & & 38 \\
\hline Star Mantle & 56 & $\mathrm{~Pb}, \mathrm{Cu}, \mathrm{Au}, \mathrm{Fe}, \mathrm{Co}, \mathrm{K}$ & \\
\hline Imperial Crown Arche & 28 & $\mathrm{~Pb}, \mathrm{Cu}, \mathrm{Fe}, \mathrm{Hg}, \mathrm{Zn}, \mathrm{Ca}, \mathrm{Au}$ & \\
\hline Imperial crown Circlet & 30 & $\mathrm{~Pb}, \mathrm{Au}, \mathrm{Cu}, \mathrm{Fe}, \mathrm{Ca}, \mathrm{Hg}, \mathrm{Sn}$ & \\
\hline Stellarium & 32 & $\mathrm{~Pb}, \mathrm{Fe}, \mathrm{Au}, \mathrm{Ca}, \mathrm{Cu}, \mathrm{Hg}$ & \\
\hline \multicolumn{4}{|l|}{ Radiance } \\
\hline Radiance & 1 & $\mathrm{~Pb}, \mathrm{Fe}, \mathrm{Zn}, \mathrm{Ca}, \mathrm{Hg}, \mathrm{Cu}$ & \\
\hline Radiance & 13 & $\mathrm{~Pb}, \mathrm{Fe}, \mathrm{Ca}, \mathrm{Cu}, \mathrm{Hg}, \mathrm{As}$ & \\
\hline Radiance & 37 & $\mathrm{~Pb}, \mathrm{Ca}, \mathrm{Fe}, \mathrm{As}, \mathrm{Hg}, \mathrm{Cu}$ & \\
\hline \multicolumn{4}{|l|}{ Glory Break } \\
\hline Glory Break & 2 & $\mathrm{~Pb}, \mathrm{Ca}, \mathrm{Fe}, \mathrm{Hg}, \mathrm{As}, \mathrm{Cu}, \mathrm{Sn}$ & 5 \\
\hline Glory Break & 3 & $\mathrm{~Pb}, \mathrm{Fe}, \mathrm{Ca}, \mathrm{As}, \mathrm{Cu}, \mathrm{Hg}$ & \\
\hline Glory Break & 7 & $\mathrm{~Pb}, \mathrm{Zn}, \mathrm{Fe}, \mathrm{Ca}, \mathrm{Hg}, \mathrm{As}$ & \\
\hline Glory Break & 9 & $\mathrm{~Pb}, \mathrm{Fe}, \mathrm{Ca}, \mathrm{As}, \mathrm{Hg}, \mathrm{Cu}$ & \\
\hline Glory Break & 10 & $\mathrm{~Pb}, \mathrm{Fe}, \mathrm{Ca}, \mathrm{Cu}, \mathrm{As}, \mathrm{Hg}$ & 32 \\
\hline Glory Break & 12 & $\mathrm{~Pb}, \mathrm{Fe}, \mathrm{Ca}, \mathrm{As}, \mathrm{Cu}, \mathrm{Hg}$ & 31 \\
\hline Glory Break & 36 & $\mathrm{~Pb}, \mathrm{Fe}, \mathrm{Ca}, \mathrm{As}, \mathrm{Hg}, \mathrm{Cu}$, & \\
\hline \multicolumn{4}{|l|}{ Holy Spirit } \\
\hline Nimbus Holy Spirit & 22 & $\mathrm{~Pb}, \mathrm{Au}, \mathrm{Cu}, \mathrm{Fe}, \mathrm{Co}, \mathrm{Hg}, \mathrm{Ca}$ & 2 \\
\hline \multicolumn{4}{|l|}{ Simulated Frame } \\
\hline Simulated Frame & 14 & $\mathrm{~Pb}, \mathrm{Cu}, \mathrm{Fe}, \mathrm{Au}, \mathrm{Ca}, \mathrm{Hg}$ & 1 \\
\hline Simulated Frame & 23 & $\mathrm{~Pb}, \mathrm{Au}, \mathrm{Cu}, \mathrm{Fe}, \mathrm{Hg}, \mathrm{Ca}, \mathrm{Sn}$ & \\
\hline Simulated Frame & 67 & $\mathrm{~Pb}, \mathrm{Fe}, \mathrm{Au}, \mathrm{Cu}, \mathrm{Ca}, \mathrm{Hg}$ & \\
\hline
\end{tabular}

Table A2. Blue.

\begin{tabular}{lccc}
\hline \multicolumn{1}{c}{ Region } & XRF ID & Elements & FORS ID \\
\hline $\begin{array}{l}\text { Virgin Mary } \\
\text { Mantle }\end{array}$ & 45 & $\mathrm{~Pb}, \mathrm{As}, \mathrm{Cu}, \mathrm{Fe}, \mathrm{Ca}, \mathrm{Co}, \mathrm{K}$ & 33,34 \\
Mantle & 46 & $\mathrm{~Pb}, \mathrm{Ca}, \mathrm{As}, \mathrm{Fe}, \mathrm{Cu}, \mathrm{Co}$ & 39 \\
Mantle & 47 & $\mathrm{~Pb}, \mathrm{Cu}, \mathrm{Fe}, \mathrm{Ca}, \mathrm{Cu}, \mathrm{K}, \mathrm{Co}$ & $\mathrm{Pb}, \mathrm{Ca}, \mathrm{As}, \mathrm{Fe}, \mathrm{Co}, \mathrm{Cu}$ \\
Mantle & 52 & $\mathrm{~Pb}, \mathrm{Cu}, \mathrm{As}, \mathrm{Fe}, \mathrm{Co}, \mathrm{Ca}, \mathrm{K}$ & 20,22 \\
Mantle & 54 & $\mathrm{~Pb}, \mathrm{Cu}, \mathrm{As}, \mathrm{Ca}, \mathrm{Fe}, \mathrm{Co}$ \\
Mantle & 55 & $\mathrm{Ca}, \mathrm{Zn}, \mathrm{Cr}, \mathrm{Sr}, \mathrm{Ti}, \mathrm{Co}, \mathrm{Fe}, \mathrm{Pb}$ \\
Mantle & 57 & $\mathrm{~Pb}, \mathrm{As}, \mathrm{Ca}, \mathrm{Cu}, \mathrm{Fe}, \mathrm{Hg}$ & 25 \\
Angel & 34 & $\mathrm{~Pb}, \mathrm{As}, \mathrm{Ca}, \mathrm{Fe}, \mathrm{Cu}, \mathrm{Hg}$ \\
Mantle & 35 & \\
Mantle & & $\mathrm{Pb}, \mathrm{Ca}, \mathrm{Zn}, \mathrm{As}, \mathrm{Fe}, \mathrm{Ti}, \mathrm{Co}$ \\
Holy Spirit celestial & & $\mathrm{Pb}, \mathrm{Ca}, \mathrm{As}, \mathrm{Fe}, \mathrm{Co}$ \\
background & 20 &
\end{tabular}


Table A3. Red.

\begin{tabular}{lccc}
\hline \multicolumn{1}{c}{ Region } & XRF ID & Elements & FORS ID \\
\hline Virgin Mary & & & \\
Lips & 42 & $\mathrm{~Pb}, \mathrm{Hg}, \mathrm{Ca}, \mathrm{Fe}, \mathrm{Cu}$ & 28 \\
Sleeve & 51 & $\mathrm{Hg}, \mathrm{Pb}, \mathrm{Fe}, \mathrm{Ca}, \mathrm{Cu}$ & 57 \\
Mantle & 58 & $\mathrm{~Pb}, \mathrm{Hg}, \mathrm{Ca}, \mathrm{Fe}, \mathrm{Cu}$ & 10 \\
Crown & 26 & $\mathrm{~Pb}, \mathrm{Hg}, \mathrm{Ca}, \mathrm{Fe}, \mathrm{Cu}$ & \\
Crown & 53 & $\mathrm{~Pb}, \mathrm{Hg}, \mathrm{Cu}, \mathrm{Fe}, \mathrm{Ca}$ & \\
\hline
\end{tabular}

Table A4. Brown.

\begin{tabular}{lccc}
\hline \multicolumn{1}{c}{ Region } & XRF ID & Elements & FORS ID \\
\hline $\begin{array}{l}\text { Virgin Mary } \\
\text { Virgin's Hair } \\
\text { Left Angel } \\
\text { Hair }\end{array}$ & 38 & $\mathrm{~Pb}, \mathrm{Fe}, \mathrm{Ca}, \mathrm{Cu}, \mathrm{As}, \mathrm{Hg}$ & 27 \\
left Angel & 16 & $\mathrm{~Pb}, \mathrm{Fe}, \mathrm{Ca}, \mathrm{Hg}, \mathrm{As}, \mathrm{Cu}, \mathrm{Au}, \mathrm{Sn}$ & \\
$\begin{array}{l}\text { Hair } \\
\text { Eye }\end{array}$ & & & 16 \\
\hline
\end{tabular}

Table A5. Green.

\begin{tabular}{lccc}
\hline \multicolumn{1}{c}{ Region } & XRF ID & Elements & FORS ID \\
\hline Virgin Mary & 27 & $\mathrm{~Pb}, \mathrm{Cu}, \mathrm{Au}, \mathrm{Fe}, \mathrm{Ca}, \mathrm{Hg}, \mathrm{Zn}$ & 14 \\
$\begin{array}{l}\text { Emerald } \\
\text { Emerald } \\
\text { palm }\end{array}$ & 29 & $\mathrm{~Pb}, \mathrm{Cu}, \mathrm{Ca}, \mathrm{Fe}, \mathrm{Hg}, \mathrm{Zn}$ & 13 \\
Lily & 86 & $\mathrm{~Pb}, \mathrm{As}, \mathrm{Ca}, \mathrm{Fe}, \mathrm{Hg}, \mathrm{Cu}$ & 58 \\
Lily & 81 & $\mathrm{~Pb}, \mathrm{As}, \mathrm{Cu}, \mathrm{Fe}, \mathrm{Hg}, \mathrm{Ca}$ & 57 \\
\hline
\end{tabular}

Table A6. Flesh tones.

\begin{tabular}{lccc}
\hline \multicolumn{1}{c}{ Region } & XRF ID & Elements & FORS ID \\
\hline $\begin{array}{l}\text { Virgin Mary } \\
\text { Head }\end{array}$ & 40 & $\mathrm{~Pb}, \mathrm{Ca}, \mathrm{Hg}, \mathrm{Fe}, \mathrm{Cu}$ & \\
Cheek & 41 & $\mathrm{~Pb}, \mathrm{Ca}, \mathrm{Hg}, \mathrm{Cu}, \mathrm{Fe}$ & \\
Angel & & $\mathrm{Pb}, \mathrm{Ca}, \mathrm{Hg}, \mathrm{Fe}, \mathrm{Cu}$ & \\
Foot & 11 & $\mathrm{~Pb}, \mathrm{Ca}, \mathrm{Hg}, \mathrm{Fe}, \mathrm{Cu}$ & 6 \\
Cheek & 17 & $\mathrm{~Pb}, \mathrm{Ca}, \mathrm{Hg}, \mathrm{Fe}, \mathrm{Cu}$ & 17,21 \\
Hand & 31 & & \\
Querubin & & $\mathrm{Pb}, \mathrm{Ca}, \mathrm{Hg}, \mathrm{Fe}, \mathrm{Cu}$ & \\
Head & 68 & $\mathrm{~Pb}, \mathrm{Hg}, \mathrm{Ca}, \mathrm{Cu}, \mathrm{Fe}$ & \\
Cheek & 70 & & \\
\hline
\end{tabular}

\section{References}

1. Cano, N.; de Lucio, O. Purísima Concepción. Tiempo y Forma de Una Pintura Novohispana; Anales del Instituto de Investigaciones Estéticas: Mexico City, Mexico, 2021.

2. Rowlands, A.; Sarris, A. Detection of exposed and subsurface archaeological remains using multi-sensor remote sensing. J. Archaeol. Sci. 2007, 34, 795-803. [CrossRef]

3. Cavalli, R.M.; Colosi, F.; Palombo, A.; Pignatti, S.; Poscolieri, M. Remote hyperspectral imagery as a support to archaeological prospection. J. Cult. Herit. 2007, 8, 272-283. [CrossRef]

4. Bassani, C.; Cavalli, R.M.; Goffredo, R.; Palombo, A.; Pascucci, S.; Pignatti, S. Specific spectral bands for different land cover contexts to improve the efficiency of remote sensing archaeological prospection: The Arpi case study. J. Cult. Herit. 2009, 10, e41-e48. [CrossRef] 
5. Fiumi, L. Surveying the roofs of Rome. J. Cult. Herit. 2012, 13, 304-313. [CrossRef]

6. Hällström, J.; Barup, K.; Grönlund, R.; Johansson, A.; Svanberg, S.; Palombi, L.; Lognoli, D.; Raimondi, V.; Cecchi, G.; Conti, C. Documentation of soiled and biodeteriorated facades: A case study on the Coliseum, Rome, using hyperspectral imaging fluorescence lidars. J. Cult. Herit. 2009, 10, 106-115. [CrossRef]

7. Pérez, M.; Arroyo-Lemus, E.; Ruvalcaba-Sil, J.; Mitrani, A.; Maynez-Rojas, M.; de Lucio, O. Technical non-invasive study of the novo-hispanic painting the Pentecost by Baltasar de Echave Orio by spectroscopic techniques and hyperspectral imaging: In quest for the painter's hand. Spectrochim. Acta Part A Mol. Biomol. Spectrosc. 2021, 250, 119225. [CrossRef] [PubMed]

8. Padoan, R.; Klein, M.E.; Groves, R.M.; de Bruin, G.; Steemers, T.A.G.; Strlič, M. Quantitative assessment of impact and sensitivity of imaging spectroscopy for monitoring of ageing of archival documents. J. Cult. Herit. 2021, 4, 105-124. [CrossRef]

9. Sun, M.; Zhang, N.; Wang, Z.; Ren, J.; Chai, B.; Sun, J. What's wrong with the murals at the Mogao Grottoes: A near-infrared hyperspectral imaging method. Sci. Rep. 2015, 5, 14371. [CrossRef] [PubMed]

10. Hou, M.; Zhou, P.; Lv, S.; Hu, Y.; Zhao, X.; Wu, W.; He, H.; Li, S.; Tan, L. Virtual restoration of stains on ancient paintings with maximum noise fraction transformation based on the hyperspectral imaging. J. Cult. Herit. 2018, 34, 136-144. [CrossRef]

11. Verougstraete, H. Frames and Supports in 15th and 16th Century-Southern Netherlandish Painting; Royal Institute for Cultural Heritage: Brussels, Belgium, 2015.

12. Moreno, P.S. Fernando Gallego and the altarpiece of Ciudad Rodrigo. In Fernando Gallego and His Workshop: The Altarpiece from Ciudad Rodrigo; Dotseth, A.W., Anderson, B.C., Roglán, M.A., Eds.; Philip Wilson Publishers: London, UK, 2008 ; p. 41.

13. Carrillo, A. Técnica de La Pintura de Nueva España; Instituto de Investigaciones Esteticas: Ciudad de México, Mexico, 1983.

14. Veganzones, M.A.; Graña, M. Endmember extraction methods: A short review. Lect. Notes Comput. Sci. 2008, 400-407. [CrossRef]

15. Karbhari, V.K.; Mahesh, M.S.; Dhananjay, B.N. Hyperspectral endmember extraction techniques. In Processing and Analysis of Hyperspectral Data; IntechOpen: London, UK, 2020; p. 13.

16. Foglini, F.; Grande, V.; Marchese, F.; Bracchi, V.A.; Prampolini, M.; Angeletti, L.; Castellan, G.; Chimienti, G.; Hansen, I.M.; Gudmundsen, M.; et al. Application of hyperspectral imaging to underwater habitat mapping, Southern Adriatic Sea. Sensors 2019, 19, 2261. [CrossRef] [PubMed]

17. Sil, J.L.R.; Miranda, D.R.; Melo, V.A.; Picazo, F. SANDRA: A portable XRF system for the study of Mexican cultural heritage. X-Ray Spectrom. 2010, 39, 338-345. [CrossRef]

18. Dooley, K.A.; Lomax, S.; Zeibel, J.G.; Miliani, C.; Ricciardi, P.; Hoenigswald, A.; Loew, M.; Delaney, J.K. Mapping of egg yolk and animal skin glue paint binders in Early Renaissance paintings using near infrared reflectance imaging spectroscopy. Analyst 2013, 138, 4838-4848. [CrossRef] [PubMed]

19. Vargaslugo, E.; Ángeles, J.P.; Gutiérrez, A.C.; Correa, J. Su Vida y Su Obra; Instituto de Investigaciones Esteticas: Ciudad de México, Mexico, 2017.

20. Rodríguez Nóbrega, J. Pintura en los reinos: Identidades compartidas. Territorios del mundo hispánico, siglos XVI-XVIII. In El Oro en la Pintura de los Reinos de la Monarquía Española-Técnica y Simbolismo; Haces, J.G., Ed.; Fomento Cultural Banamex: Mexico City, Mexico, 2009; pp. 1314-1375.

21. Aceto, M.; Agostino, A.; Fenoglio, G.; Idone, A.; Gulmini, M.; Picollo, M.; Ricciardi, P.; Delaney, J.K. Characterisation of colourants on illuminated manuscripts by portable fibre optic UV-visible-NIR reflectance spectrophotometry. Anal. Methods 2014, 6, 1488-1500. [CrossRef]

22. Arroyo, E.; Espinosa, M.E.; Falcón, T.; Hernández, E. Variaciones celestes para pintar el manto de la Virgen. An. Inst. Investig. Estéticas 2012, 34, 85-117. [CrossRef]

23. Picollo, M.; Bacci, M.; Magrini, D.; Radicati, B.; Trumpy, G.; Tsukada, M.; Kunzelman, D. Modern white pigments: Their identification by means of noninvasive ultraviolet, visible, and infrared fiber optic reflectance spectroscopy. In Modern Paints Uncovered, Proceedings of the Modern Paints Uncovered Symposium, London, UK, 16-19 May 2006; Getty Conservation Institute: Los Angeles, CA, USA, 2007; pp. 118-128. 